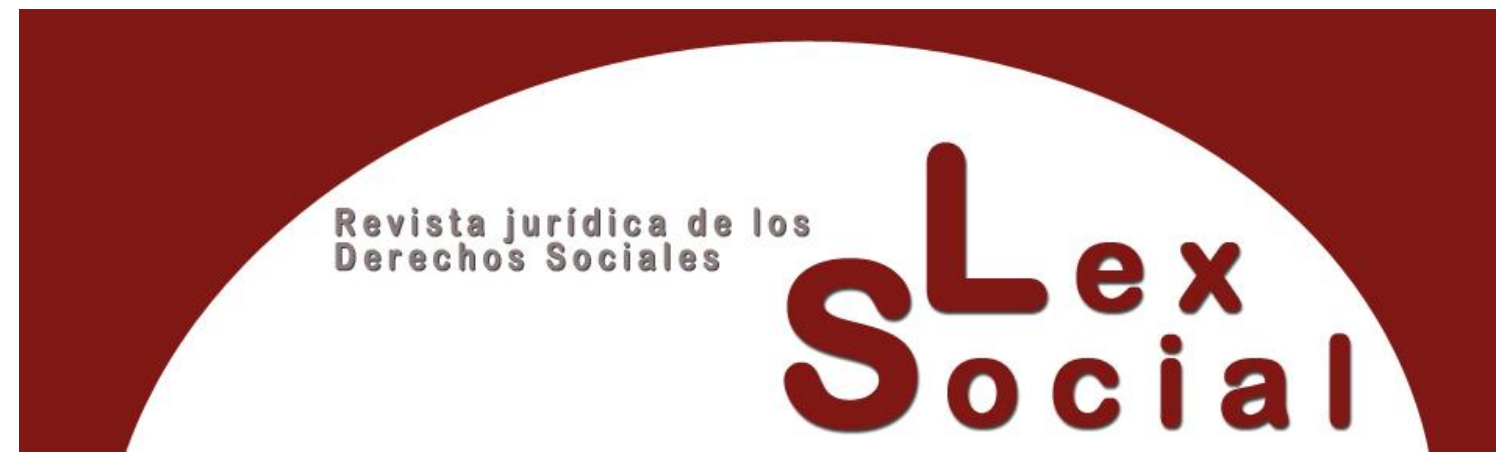

\title{
IMPUGNACIÓN JURISDICCIONAL DEL DESPIDO COLECTIVO: ESPECIAL REFERENCIA A LOS CRITERIOS DE SELECCIÓN
}

\section{JUDICIAL CHALLENGE OF COLLECTIVE DISMISSALS: SPECIAL REFERENCE TO WORKERS'SELECTION CRITERIA}

\author{
JUAN ALBERTO TORMOS PÉREZ \\ Profesor ayudante doctor Derecho del Trabajo y Seguridad Social \\ Universitat de València \\ https://orcid.org/0000-0001-8829-192X
}

Cómo citar este trabajo: Tormos Pérez, J.A. (2021). Impugnación jurisdiccional del despido colectivo: especial referencia a los criterios de selección. Lex Social: Revista de Derechos Sociales, 11(1), 243-283. https://doi.org/10.46661/lexsocial.5476

\begin{abstract}
RESUMEN
En el presente estudio se analiza el sistema de impugnación judicial del despido colectivo, con una especial referencia a las cuestiones atinentes a la afectación de los trabajadores, como consecuencia de la aplicación de los conocidos como criterios de selección, así como el juego de las reglas de prioridad de permanencia. Se analizan todas las vías y motivos de impugnación que tienen los trabajadores afectados por el despido colectivo, tanto en la vertiente colectiva como en la individual.
\end{abstract}

Palabras clave: despido colectivo, impugnación jurisdiccional, criterios de selección, prioridad de permanencia. 


\begin{abstract}
In this work, the system of judicial challenge for collective dismissals is analysed, with a special reference to issues related to affected workers, as a consequence of the application of the so-called selection criteria, as well as the rules of permanence priority. It also analyses all the possibilities and grounds for judicial challenging at the disposal of affected workers, both in the collective and individual aspects.
\end{abstract}

KEYWORDS: collective dismissal, judicial challenge, selection criteria, permanence priority.

SUMARIO

I. Introducción.

II. El modelo de impugnación tras la reforma laboral de 2012.

1. Impugnación de oficio por la autoridad laboral.

2. Acción declarativa a instancias del empresario.

III. La modalidad procesal colectiva de impugnación del despido colectivo.

1. Motivos de impugnación por la vía del art. 124 LRJS.

2. Otras cuestiones procesales: legitimación y competencia.

3. Contenido de la sentencia de impugnación del despido colectivo.

3.1. Declaración del carácter ajustado a derecho de la decisión extintiva.

3.2. Declaración del carácter no ajustado a derecho de la decisión extintiva.

3.3. Declaración de nulidad de la decisión extintiva.

4. Aportación insuficiente o defectuosa de la documentación pertinente.

4.1. Aportación de la documentación legal y reglamentaria.

4.2. Aportación de los extremos del art. 51.2 ET: interpretación finalista.

4.3. No aportación del desglose de los afectados por clasificación profesional y/o por centros, provincia o comunidad autónoma.

4.4. Aportación suficiente de los criterios de selección: nivel de concreción.

4.5. Aportación tardía de la documentación.

4.6. Obligaciones documentales: recapitulación.

5. Vulneración de los derechos fundamentales y libertades públicas.

IV. La modalidad de impugnación individual de los despidos.

1. Configuración procesal de la impugnación individual.

2. Nulidad por no respetar las reglas de prioridad de permanencia.

V. Conclusiones.

Bibliografía.

\title{
I. Introducción.
}


El artículo 51.6 del Estatuto de los Trabajadores (ET) prevé la posibilidad de impugnar judicialmente el despido colectivo conforme a la modalidad procesal de despido colectivo prevista en el art. 124 de la Ley 36/2011, de 10 de octubre, reguladora de la jurisdicción social (LRJS). Concluida la fase colectiva del despido colectivo, centrada en la negociación llevada a cabo durante el período de consultas, los representantes de los trabajadores pueden impugnar la decisión empresarial de despido. Por su parte, finalizada la fase individual del despido colectivo -en la que el empresario notifica individualmente la decisión a los trabajadores afectados-, dichos trabajadores también podrán impugnar individualmente su despido.

La posibilidad de impugnación jurisdiccional forma parte de la conocida fase de control del despido colectivo, más en concreto de control judicial, en la que los tribunales tienen que determinar si el despido colectivo en general, y los criterios de selección de los trabajadores afectados y su aplicación en particular, se ajustan a lo señalado en el ordenamiento jurídico. En el presente estudio se plantean numerosos interrogantes, pues el carácter discrecional del que goza el empresario en su facultad de determinación y aplicación de los criterios de selección plantea la duda de hasta qué punto es posible un control judicial sobre la materia, y con qué parámetros. En este punto, es evidente que el control judicial se encargará también de controlar que el ejercicio de dicha facultad respeta los límites que prevé el ordenamiento jurídico, tanto los generales como los específicos relativos a los criterios de selección, como por ejemplo el respeto a las conocidas como reglas de prioridad de permanencia.

\section{El modelo de impugnación tras la reforma laboral de 2012.}

Así las cosas, el art. 51.6 ET contempla, desde el año 2012, un modelo de impugnación judicial caracterizado por la existencia de dos vías impugnatorias: una colectiva planteada por parte de los representantes de los trabajadores, y una individual planteada por parte de cada uno de los trabajadores afectados, así como la posibilidad de que la autoridad laboral impugne los acuerdos alcanzados en el período de consultas.

El nuevo modelo de despido colectivo surgido tras la aprobación de la reforma laboral de 2012 hizo necesaria la creación de una nueva modalidad procesal, atendiendo al hecho de que la autorización administrativa previa a los despidos había desaparecido del ordenamiento. Por ello, tanto el Real Decreto-ley 3/2012 (art. 23) como la Ley 3/2012 (art. 23) incluyeron disposiciones para reformar varios aspectos de la LRJS, creando y desarrollando una nueva modalidad procesal de impugnación de despido colectivo. En este sentido, el art. 124 LRJS regula una modalidad procesal de impugnación de despido colectivo.

Se trata de una modificación importante, ya que se da traslación al plano procesal de las modificaciones operadas por la reforma laboral de 2012 en relación al despido colectivo. Como consecuencia de ello, la modalidad procesal de impugnación de despidos colectivos prevista en el art. 124 LRJS, tras las reformas operadas en la LRJS por el Real 
Decreto-ley 3/2012, de 10 de febrero, la Ley 3/2012, de 6 de julio, y el posterior Real Decreto-ley 11/2013, de 2 de agosto, ha suscitado interesantes debates y ha sido ampliamente comentada por la doctrina. ${ }^{1}$

La reforma laboral de 2012, al suprimir la autorización administrativa ${ }^{2}$ previa al despido colectivo, supone el paso de un control administrativo y ex ante de los supuestos de regulación de empleo, a un control judicial y ex post previa decisión unilateral del empresario, como en el resto de supuestos de despido. ${ }^{3}$ No obstante, el cambio de modelo no ha traído consigo una mayor simplificación del control de los despidos colectivos. Así, el modelo de impugnación judicial del despido colectivo tras la reforma laboral de 2012 reviste una considerable complejidad, y está compuesto por una "amalgama" de impugnaciones que dan lugar a no pocos problemas jurídicos y de articulación. ${ }^{4}$

El modelo de impugnación judicial del despido colectivo contemplado en el art. 124 LRJS con posterioridad a la reforma laboral de 2012 contempla cuatro formas distintas de impugnación o acciones frente a la decisión empresarial. Dichas acciones o impugnaciones son:

\footnotetext{
${ }^{1}$ Sobre esta cuestión, véase PRECIADO DOMÈNECH, Carlos Hugo, El nuevo proceso de despido colectivo en la Ley 3/2012, de 6 de julio, Albacete, Bomarzo, 2013, p. 5 y ss.; AGUSTÍ MARAGALL, Joan, "Más cuestiones sobre el nuevo proceso judicial de impugnación colectiva del despido colectivo (art. 124 LRJS)", Jurisdicción Social, núm. 118, 2012; TASCÓN LÓPEZ, Rodrigo, "Problemas prácticos en la impugnación del despido colectivo", Aranzadi Social: Revista Doctrinal, núm. 10, 2013; GIL PLANA, Juan, "Reforma procesal del despido colectivo y otras novedades procesales", en: THIBAULT ARANDA, Javier (dir.), JURADO SEGOVIA, Ángel (coord.), La reforma laboral de 2012: nuevas perspectivas para el derecho del trabajo, Madrid, La Ley, 2012.

${ }^{2}$ Sobre la regulación del despido, véase PUEBLA PINILLA, Ana de la, "Las paradojas del despido colectivo tras la supresión de la autorización administrativa", Teoría y Derecho, núm. 13, 2013; GIL PLANA, Juan, "El despido colectivo: aspectos sustantivos", en VV.AA., MONTOYA MELGAR, Antonio, GARCÍA MURCIA, Joaquín (dirs.), Comentario a la reforma laboral de 2012, Madrid, Civitas, 2012; GOÑI SEIN, José Luis, "El nuevo modelo normativo de despido colectivo implantado por la Ley de reforma laboral de 2012", Documentación Laboral, núm. 95-96, 2012; MONEREO PÉREZ, José Luis, "El nuevo procedimiento de regulación de empleo (en contraste con el antes denominado "expediente" de crisis)", Revista General de Derecho del Trabajo y de la Seguridad Social, núm. 34, 2013; y MONEREO PÉREZ, José Luis, "Intervención administrativa en los despidos colectivo", Temas Laborales: Revista Andaluza de Trabajo y Bienestar Social, núm. 125, 2014.

${ }^{3}$ Así lo ha remarcado en la doctrina GOERLICH PESET, José María, "La extinción del contrato de trabajo en la reforma de 2012: la culminación de una larga evolución", en: GARCÍA-PERROTE ESCARTÍN, Ignacio, MERCADER UGUINA, Jesús Rafael, (dirs.), La regulación del Mercado Laboral. Un análisis de la Ley 3/2012 y de los aspectos laborales del Real Decreto-ley 20/2012, Valladolid, Lex Nova, 2012, p. 357.

${ }^{4}$ Véase BLASCO PELLICER, Ángel Antonio, "El proceso de impugnación del despido colectivo: el objeto del procedimiento. Las pretensiones posibles", en: GODINO REYES, Martín (dir.), Tratado de despido colectivo, València, Tirant lo Blanch, 2016, p. 559-561, quien señala que hay que estar, de manera especial, a las relaciones o articulación entre las distintas impugnaciones. La doctrina ha criticado la regulación de todas estas vías de impugnación, ya que el legislador no ha resuelto con detalle cómo se coordinan entre ellas, lo cual genera el riesgo de que, sobre un mismo procedimiento de despido colectivo, recaigan resoluciones judiciales contradictorias, como también destaca DESDENTADO BONETE, Aurelio, "Comentario al artículo 124 LRJS", en: MERCADER UGUINA, Jesús Rafael (dir.), Ley reguladora de la jurisdicción social comentada y con jurisprudencia, Madrid, La Ley, 2015, p. 804.
} 
- Acción de despido colectivo a instancia de los representantes legales de los trabajadores, o de los representantes sindicales que tengan implantación suficiente, contemplada en el art. 124.1 y 124.2 LRJS y art. 51.6 ET.

- Acción individual de despido a instancias del trabajador afectado, contemplada en el art. 124.13 LRJS en relación con los arts. 120-123 LRJS, y cuya tramitación queda paralizada por la interposición de la demanda colectiva por los representantes de los trabajadores (art. 51.6 ET).

- Impugnación de oficio por la autoridad laboral respecto del acuerdo alcanzado en el período de consultas, de conformidad con el art. 148 b) LRJS.

- Acción declarativa a instancias del empresario, contemplada en el art. 124.3 LRJS, en ausencia de impugnación colectiva e impugnación de oficio, con la finalidad de que se declare el carácter ajustado a derecho de la decisión extintiva.

Las dos principales modalidades de impugnación, y que se corresponden con las dos fases del despido colectivo (colectiva e individual), son, por un lado, la modalidad de impugnación colectiva por parte de los representantes de los trabajadores y, por otro, la modalidad de impugnación individual por parte del trabajador afectado. La impugnación colectiva pretende efectuar un control sobre la legalidad de la fase colectiva del despido colectivo, mientras que la impugnación individual controla la ejecución individual de dicho despido colectivo. Las otras dos modalidades de impugnación (de oficio por la autoridad laboral y la acción declarativa empresarial) revisten un carácter subsidiario y, a pesar de algunas dudas, una naturaleza eminentemente colectiva. Las distintas modalidades de impugnación dan lugar a un complejo sistema en el que la articulación de las distintas acciones no ha sido convenientemente resuelta por el legislador.

El Tribunal Supremo se ha pronunciado sobre este modelo de control judicial del despido colectivo, debiendo destacar la STS (Social) de 20 de octubre de 2013 (Rec. 11/2013) ha interpretado los aspectos procesales en materia de despido colectivo tras la reforma laboral de 2012. ${ }^{5}$ Así, califica el modelo de impugnación del despido colectivo como una "compleja maquinaria procesal", en la que el legislador ha buscado dos finalidades: evitar la disparidad de resoluciones judiciales individuales en caso de que se les permitiera analizar todos los aspectos del procedimiento de despido colectivo, y simplificar el control judicial mediante un reparto competencial entre las Salas de lo Social de los Tribunales Superiores de Justicia (cuestiones colectivas) y los Juzgados de lo Social (cuestiones individuales). ${ }^{6}$

\footnotetext{
${ }^{5}$ Aunque dicha Sentencia ha sido posteriormente anulada por el Auto TS de 26 de marzo de 2014 (incidente de nulidad de actuaciones 11/2013) por incongruencia extra petita, la doctrina contenida sobre la reforma laboral resulta de gran interés.

${ }^{6}$ La STS (Social) de 20 de octubre de 2013 (Rec. 11/2013) señala: "La diferenciación de las vías procesales del artículo 124 LRJS se apoya en último término en la distinción de los respectivos objetos de las acciones correspondientes. La acción del artículo 124.1 LRJS [...] tiene por objeto la decisión extintiva colectiva (“despido colectivo"). La acción del actual artículo 124.13 LRJS (124.11 LRJS en el RDL 3/2012) tiene por objeto los actos subsiguientes de despido formalizados por carta que se comunican a los trabajadores despedidos."
} 


\section{Impugnación de oficio por la autoridad laboral. ${ }^{7}$}

Tras la reforma laboral de 2012, la LRJS sigue manteniendo el proceso de impugnación oficio del art. 148 b) LRJS, que permite a la autoridad laboral impugnar los eventuales acuerdos alcanzados en período de consultas si estima que se han alcanzado con fraude, dolo, coacción o abuso de derecho, así como cuando la entidad gestora de las prestaciones por desempleo - es decir, el Servicio Público de Empleo Estatal-, hubiese informado de que la decisión extintiva empresarial pudiera esconder la obtención indebida de prestaciones.

Se trata pues de un control que la autoridad laboral realiza de forma indirecta sobre el procedimiento de despido colectivo, una vez que ha desaparecido su anterior potestad de autorizar o no los despidos. ${ }^{8}$ En los supuestos previstos en dicho precepto, la sentencia declarará la nulidad del despido colectivo. ${ }^{9}$ La impugnación de oficio por la autoridad laboral tiene un cierto carácter subordinado a la impugnación colectiva que eventualmente puedan interponer los representantes de los trabajadores, tal y como lo demuestra el art. 124.7 LRJS, al señalar que la impugnación de oficio quedará en suspenso cuando se haya iniciado una impugnación colectiva. Por su parte, la referencia del art. 124.3 LRJS a que la acción declarativa empresarial sólo podrá plantearse cuando no haya habido impugnación colectiva ni impugnación de oficio por la autoridad laboral, viene a conferir a ésta última efectos de carácter colectivo y de cosa juzgada sobre los procesos individuales que pudieran plantearse.

Ciertamente, no es frecuente encontrar supuestos de despido colectivo en que se incurra en alguno de los vicios mencionados, pero la razón de ser de esta acción impugnatoria es que los poderes públicos se defiendan de posibles acuerdos o decisiones empresariales que puedan suponer una carga para el Estado, por ejemplo, por implicar fraude a las prestaciones de desempleo. En este sentido, es necesario que la autoridad laboral aporte indicios suficientes relativos a que el acuerdo o decisión incurre en alguno de los vicios mencionados..$^{10}$

\footnotetext{
${ }^{7}$ Sobre esta modalidad de impugnación, véase SÁEZ LARA, Carmen, Reestructuraciones empresariales y despidos colectivos, València, Tirant lo Blanch, 2015, p. 290-293.

${ }^{8}$ Así lo aprecia en la doctrina GOERLICH PESET, J. M., "La extinción del contrato de trabajo en la reforma de 2012: la culminación de una larga evolución", op. cit., p. 361. Sobre el dolo, coacción o abuso de derecho, cabe citar la STS (Social) de 15 de julio de 1994 (Rec. 2321/1991), que define los conceptos de dolo, coacción o intimidación, y abuso de derecho.

${ }^{9}$ Así lo entiende PRECIADO DOMÈNECH, C. H., El nuevo proceso de despido colectivo en la Ley 3/2012, de 6 de julio, op. cit., p. 45. El argumento principal atiende al hecho de que los supuestos de fraude de ley, abuso de derecho, dolo o coacción atentan contra los derechos fundamentales, además de que en la normativa laboral se encuentran otros supuestos de fraude a las normas procedimentales mediante acuerdo colectivo cuya sanción es también la nulidad, como el caso del art. 51.1 in fine ET, sobre los despidos objetivos en períodos sucesivos de 90 días, y el art. 138.7 LRJS, sobre procedimientos de movilidad geográfica, modificación sustancial de condiciones de trabajo, suspensión del contrato de trabajo y reducción de jornada.

${ }^{10}$ La STS (Contencioso-administrativo) de 26 de enero de 2004 (Rec. 6769/2000) señala que "la concurrencia de conductas susceptibles de ser encuadradas en tales vicios del consentimiento [coacciones, dolo y abuso de derecho] no ha sido acreditada", por lo que desestima el recurso de los representantes de los trabajadores.
} 


\section{Acción declarativa a instancias del empresario.}

El art. 124.3 LRJS prevé la posibilidad de que el empresario interponga una demanda a fin de que la decisión adoptada en el procedimiento de despido colectivo sea declarada ajustada a derecho, únicamente en los supuestos en que ni los representantes legales o sindicales de los trabajadores, ni la autoridad laboral hayan impugnado el procedimiento, y transcurridos los 20 días de plazo de caducidad que los representantes tienen para impugnar. ${ }^{11}$

El objetivo de esta acción declarativa introducida tras la reforma laboral de 2012 es evitar la dispersión que generarían los múltiples procesos individuales posteriores en aquellos supuestos en que no haya habido una impugnación colectiva, de modo que pueda haber un control judicial único y mayor seguridad jurídica. ${ }^{12}$ Por ello, la sentencia declarativa que se dicte tendrá efectos de cosa juzgada sobre los procesos individuales -tanto en el orden social como en el contencioso-administrativo- que se insten sobre idéntico objeto o en relación con él, en el sentido del art. 160.5 LRJS en materia de conflictos colectivos. ${ }^{13}$ Es precisamente en este efecto de cosa juzgada donde se encuentra la razón de ser de la regulación de esta forma de impugnación, que no es otra que evitar que las ulteriores impugnaciones individuales entren a discutir sobre el carácter eventualmente no ajustado a derecho o nulo de la decisión empresarial, en aquellos supuestos en que no haya habido impugnación colectiva por parte de los representantes de los trabajadores ni impugnación de oficio por parte de la autoridad laboral. ${ }^{14}$

Con anterioridad a la reforma operada por el Real Decreto-ley 11/2013, la doctrina ha discutido acerca de si esta acción declarativa empresarial -o la planteada de oficio a instancias de la autoridad laboral- suspende el plazo de caducidad de las acciones individuales. Hay que considerar que, con independencia de la posterior aclaración vía legislativa, la respuesta debía ser afirmativa, debido a la naturaleza colectiva de la acción,

\footnotetext{
${ }^{11}$ Aunque en algunas ocasiones se la ha denominado inapropiadamente "acción de jactancia", la mayoría de la doctrina ha admitido la legitimidad de la presente acción impugnatoria, que atiende un interés legítimo del empresario, cual es que su decisión colectiva no sea enjuiciada de modo dispar en innumerables procesos individuales en aquellos casos en que no haya sido impugnada por la vía colectiva. Así, la acción surge de un interés real y efectivo del empresario de lograr el efecto positivo de cosa juzgada respecto del despido colectivo, y así protegerse frente a futuras impugnaciones individuales, como acertadamente señalan DESDENTADO BONETE, A., "Comentario al artículo 124 LRJS", op. cit., p. 818; y BLASCO PELLICER, Á., "El proceso de impugnación del despido colectivo: el objeto del procedimiento. Las pretensiones posibles", op. cit., p. 577.

${ }^{12}$ Así lo aprecian BLASCO PELLICER, Ángel Antonio, La extinción del contrato de trabajo en la reforma laboral de 2012, València, Tirant lo Blanch, 2013, p. 105; FOLGUERA CRESPO, José Ángel, "El impacto de la reforma laboral en el proceso", en: GARCÍA-PERROTE ESCARTÍN, Ignacio, MERCADER UGUINA, Jesús Rafael, (dirs.), La aplicación práctica de la reforma laboral: un estudio de Ley 3/2012 y de los Reales Decretos-leyes 4/2013 y 5/2013, Valladolid, Lex Nova, 2013, p. 374; y TASCÓN LÓPEZ, Rodrigo, "La impugnación del despido colectivo tras la reforma laboral: el Derecho del Trabajo en su laberinto", Revista de Trabajo y Seguridad Social, núm. 353-354, 2012, p. 24.

${ }^{13} \mathrm{El}$ art. 160.5 LRJS señala: "La sentencia firme producirá efectos de cosa juzgada sobre los procesos individuales pendientes de resolución o que puedan plantearse, que versen sobre idéntico objeto o en relación de directa conexidad con aquél, tanto en el orden social como en el contencioso-administrativo, que quedarán en suspenso durante la tramitación del conflicto colectivo."

${ }^{14}$ Véase PRECIADO DOMÈNECH, C. H., El nuevo proceso de despido colectivo en la Ley 3/2012, de 6 de julio, op. cit., p. 7-8.
} 
que la asimila al proceso de impugnación instado por los representantes de los trabajadores. ${ }^{15}$ El Real Decreto-ley 11/2013 resolvió las dudas, al incorporar un inciso final al art. 124.3 LRJS que señala que "la presentación de la demanda por el empresario suspenderá el plazo de caducidad de la acción individual del despido".

La doctrina entiende que la naturaleza jurídica de esta acción es la de un proceso colectivo que plantea el empresario como titular del interés general de la empresa. ${ }^{16} \mathrm{Su}$ finalidad es, al igual que en la impugnación colectiva planteada a instancias de la representación de los trabajadores, obtener una respuesta judicial única y válida para todo el procedimiento de despido colectivo, evitando así ulteriores demandas individuales en ausencia de demanda colectiva.

\section{La modalidad procesal colectiva de impugnación del despido colectivo.}

Tras la reforma laboral de 2012 y la supresión de la antigua autorización administrativa, la decisión empresarial de despido y la comunicación de la misma a los trabajadores afectados cobra un papel de vital importancia, ya que en cierto modo viene a sustituir la anterior autorización administrativa como acto "habilitante" del despido. Como ha señalado la doctrina, constituye la "premisa ontológica" que permite la extinción de los contratos de trabajo afectados por la causa de despido. De este modo, la decisión empresarial -bien unilateral, o bien acordada con los representantes-constituye el objeto de impugnación judicial a efectos del art. 51.6 ET y art. 124 LRJS. ${ }^{17}$

El objeto de esta modalidad es, exclusivamente, la impugnación de la decisión colectiva adoptada por el empresario al final del procedimiento de despido. En consecuencia, ninguna cuestión atinente a la posterior fase individual del despido podrá ser objeto de esta modalidad procesal, en particular las cuestiones que se refieran a la afectación individual del trabajador en la medida extintiva, es decir, a la aplicación de los criterios de selección, o a la aplicación de reglas de prioridad de permanencia. En este sentido, y así lo señala expresamente la ley, no podrán ser objeto de este proceso "las pretensiones relativas a la inaplicación de las reglas de prioridad de permanencia previstas legal o convencionalmente o establecidas en el acuerdo adoptado en el período de consultas" (art.

\footnotetext{
15 Esta misma postura adopta MOLERO MARAÑÓN, María Luisa, "La nueva modalidad procesal de impugnación judicial del despido colectivo”, Relaciones Laborales, núm. 23-24, 2012.

16 Así lo señala BALLESTER LAGUNA, Fernando, La impugnación del despido colectivo (en el marco del artículo 124 de la Ley 36/2011, de 10 de octubre, reguladora de la jurisdicción social), València, Tirant lo Blanch, 2013, p. 138.

${ }^{17}$ Sobre esta modalidad procesal, vid. BLASCO PELLICER, Á., "El proceso de impugnación del despido colectivo: el objeto del procedimiento. Las pretensiones posibles", op. cit., p. 562; BODAS MARTÍN, Ricardo, "Modificaciones de la Ley 36/2011, de 10 de octubre, reguladora de la jurisdicción social, producidas por la Ley 3/2012, de 6 de julio", en: GARCÍA-PERROTE ESCARTÍN, Ignacio, MERCADER UGUINA, Jesús Rafael, (dirs.), Reforma laboral 2012. Análisis práctico del RDL 3/2012, de medidas urgentes para la reforma del mercado laboral, Valladolid, Lex Nova, 2012, p. 508 y ss.; y LOUSADA AROCHENA, José Francisco, RON LATAS, Ricardo Pedro, "La modalidad procesal de despidos colectivos", Diario La Ley, núm. 7863, 2012.
} 
124.2 LRJS in fine), ya que dichas impugnaciones se residencian en la modalidad individual de despido objetivo del art. 124.13 LRJS. ${ }^{18}$

En consecuencia, el proceso de impugnación colectiva tiene una "innegable naturaleza" de conflicto colectivo. ${ }^{19}$ Ello se manifiesta en distintos aspectos: en cuanto al objeto, el proceso colectivo excluye expresamente de su objeto las pretensiones de carácter individual, como la aplicación de las reglas de prioridad de permanencia legal o convencionalmente establecidas (art. 124.2 LRJS); en cuanto a la legitimación, ésta se confiere únicamente a los representantes de los trabajadores y al empresario; y en cuanto a sus efectos, la tramitación del mismo producirá la suspensión de las impugnaciones individuales ya presentadas o que puedan presentarse, así como la suspensión del plazo de caducidad de las mismas (art. 124.6 LRJS). Además, la sentencia recaída en el proceso de impugnación de despido colectivo tendrá efectos de cosa juzgada sobre los procesos individuales, de conformidad con el art. 124.13 b) $2^{\circ}$ de la LRJS. En definitiva, se trata de un proceso que afecta a "intereses generales de un grupo genérico de trabajadores" y su objeto es una decisión empresarial de carácter colectivo. ${ }^{20}$

\section{Motivos de impugnación por la vía del art. 124 LRJS.}

La demanda de impugnación del despido colectivo ex art. 124.2 LRJS puede fundarse en los siguientes motivos:

- No concurrencia de la causa legal alegada en la comunicación inicial, de conformidad con el marco causal expresado en el art. 51.1 ET.

- No realización del período de consultas o no entrega de la documentación prevista en el art. 51.2 ET. Este motivo de impugnación pretende controlar la "regularidad procedimental" de la fase colectiva del despido colectivo, ${ }^{21}$ es decir, si existen vicios en el desarrollo del período de consultas o en la documentación entregada a los representantes de los trabajadores y a la autoridad laboral junto con la comunicación de inicio.

\footnotetext{
${ }^{18}$ Así lo señaló la Audiencia Nacional en sus primeros pronunciamientos tras la reforma laboral de 2012, como por ejemplo en la SAN (Social) de 21 de noviembre de 2012 (Proc. 167/2012), que señala: "Parece claro, por tanto, que la empresa no respetó, al iniciar el período de consultas, la prioridad de permanencia de los representantes de los trabajadores, exigida por los arts. 51.5 y 68 b) ET [...], pero dicha infracción no constituye per se causa de nulidad del despido colectivo, puesto que el art. 124.2 LRJS dispone que en ningún caso podrán ser objeto del proceso de despido colectivo las pretensiones relativas a la inaplicación de las reglas de prioridad de permanencia, previstas legal, convencionalmente, o en el propio proceso de negociación del período de consultas, que deberán plantearse en los procedimientos individuales correspondientes."

${ }^{19}$ En estos términos lo señala PRECIADO DOMÈNECH, C. H., El nuevo proceso de despido colectivo en la Ley 3/2012, de 6 de julio, op. cit., p. 9.

${ }^{20}$ Véase sobre esta cuestión PRECIADO DOMÈNECH, C. H., El nuevo proceso de despido colectivo en la Ley 3/2012, de 6 de julio, op. cit., p. 9, y art. 153.1 LRJS sobre procesos de conflicto colectivo. Por su parte, MOLERO MARAÑÓN, M. L., "La nueva modalidad procesal de impugnación judicial del despido colectivo", op. cit., p. 45, señala que la sentencia posee un efecto "normativo" o "cuasi normativo".

${ }^{21}$ En estos términos se pronuncia BLASCO PELLICER, Á., La extinción del contrato de trabajo en la reforma laboral de 2012, op. cit., p. 103.
} 
- Existencia de fraude, dolo, coacción o abuso de derecho en la adopción de la decisión extintiva, lo cual cabe entender relativo a la regularidad del acuerdo alcanzado en período de consultas.

- Vulneración de derechos fundamentales y libertades públicas en la adopción de la decisión extintiva, motivo común a todas las formas de extinción del contrato.

A todo ello, el art. 124.2 LRJS añade la previsión ya señalada de que en ningún caso podrá impugnarse por vía colectiva la aplicación de las reglas de prioridad de permanencia. Se trata, pues, de una modalidad procesal que permite la impugnación de todos aquellos aspectos que afecten colectivamente al procedimiento. Así, por ejemplo, la modalidad de impugnación colectiva es la adecuada para discutir la regularidad y suficiencia de los criterios de selección pactados o adoptados por el empresario, pero no su aplicación individualizada.

Por otro lado, y sobre el ámbito subjetivo del proceso, hay que tener en cuenta que el proceso de impugnación colectiva del art. 124 LRJS es también de aplicación a la extinción de contratos de trabajo del personal laboral del sector público, al cual sin ninguna duda se le aplican las normas de despido colectivo ex D.A. 16 ${ }^{\mathrm{a}}$ ET. A ese respecto, habrá que estar a las especialidades que la D.A. 16 ${ }^{\mathrm{a}}$ ET y los arts. 34 a 48 del Reglamento de procedimiento de despido colectivo (RPDC), aprobado por Real Decreto 1483/2012, de 29 de octubre, establecen para el despido colectivo en el sector público, como es, en particular, la prioridad de permanencia del personal laboral fijo que haya adquirido tal condición mediante un proceso selectivo convocado al efecto basado en los principios de igualdad, mérito y capacidad (art. 41 RPDC). ${ }^{22}$

\section{Otras cuestiones procesales: legitimación y competencia.}

Es interesante mencionar otros aspectos que configuran esta modalidad procesal, en particular las cuestiones atinentes a la legitimación. ${ }^{23}$ Por lo que respecta a la legitimación activa, ésta corresponde a los "representantes legales o sindicales de los trabajadores". En el caso de los representantes sindicales, la jurisprudencia les exige una implantación suficiente en el ámbito en el que se lleve a cabo el despido colectivo. Por otro lado, por representantes de los trabajadores hay que entender también la eventual comisión

\footnotetext{
${ }^{22}$ Véase AGUSTÍ MARAGALL, J., "Más cuestiones sobre el nuevo proceso judicial de impugnación colectiva del despido colectivo (art. 124 LRJS)", op. cit., p. 17.

${ }^{23}$ Sobre legitimación activa y legitimación pasiva en el proceso de impugnación de despido colectivo, véase SAN CRISTÓBAL VILLANUEVA, Juan Manuel, "El proceso de impugnación del despido colectivo: legitimación activa y pasiva", en: GODINO REYES, Martín (dir.), Tratado de despido colectivo, València, Tirant lo Blanch, 2016; AGUSTÍ MARAGALL, Joan, "La coordinación entre el proceso colectivo de impugnación y los procesos individuales contra los despidos derivados del despido colectivo", en: GODINO REYES, Martín (dir.), Tratado de despido colectivo, València, Tirant lo Blanch, 2016, p. 783; BODAS MARTÍN, R., "Modificaciones de la Ley 36/2011, de 10 de octubre, reguladora de la jurisdicción social, producidas por la Ley 3/2012, de 6 de julio", op. cit., p. 524-526; y PRECIADO DOMËNECH, C. H., El nuevo proceso de despido colectivo en la Ley 3/2012, de 6 de julio, op. cit., p. 29 y ss.
} 
nombrada ad hoc para negociar en el período de consultas en ausencia de otra forma de representación. ${ }^{24}$

Por lo que respecta a la legitimación pasiva, no cabe duda de que corresponde a quien adopta la decisión de despido colectivo impugnada: el empresario. Siguiendo la misma lógica, y de acuerdo con lo establecido en el art. 124.4 LRJS, en caso de que el procedimiento de despido finalice con acuerdo, se establece un supuesto de litisconsorcio pasivo necesario, pues junto con el empresario habrá que demandar también a la representación de los trabajadores que haya suscrito dicho acuerdo.

En cuanto a la competencia, será competente la Sala de lo Social del Tribunal Superior de Justicia de la comunidad autónoma correspondiente cuando el despido colectivo no despliegue sus efectos más allá de ésta (art. 7 LRJS); ${ }^{25}$ y la Sala de lo Social de la Audiencia Nacional (art. 8.1 LRJS) cuando el despido colectivo despliegue sus efectos más allá del ámbito de una comunidad autónoma. ${ }^{26}$ La sentencia que se dicte será recurrible en casación ordinaria (art. 124.11 LRJS).

El reparto competencial en materia de impugnación colectiva excluye, pues, a los Juzgados de lo Social (art. 6 LRJS), que en ningún caso serán competentes para el conocimiento de impugnaciones de despidos colectivos, reservando para su conocimiento las impugnaciones de carácter individual, según el modelo de reparto competencial configurado en la reforma laboral de 2012.

Para muchos autores, no es casual que la competencia se haya asignado a los Tribunales Superiores de Justicia. ${ }^{27}$ En este sentido, el conocimiento directamente por los TSJ con posibilidad directa de recurso de casación ordinaria ante el TS refuerza la idea de que la intención del legislador era que los asuntos llegasen pronto a la máxima instancia jurisdiccional y se sentase jurisprudencia que clarificase la aplicación de las normas en materia de despido colectivo, contribuyendo así al propósito de una mayor objetivación de la normativa laboral en la materia. ${ }^{28}$

\footnotetext{
${ }^{24}$ Así lo señala BLASCO PELLICER, Á., La extinción del contrato de trabajo en la reforma laboral de 2012, op. cit., p. 104, y STSJ de Cataluña (Social) de 23 de mayo de 2012 (Proc. 10/2012).

${ }^{25}$ Sobre ello, vid. AGUSTÍ MARAGALL, J., "La coordinación entre el proceso colectivo de impugnación y los procesos individuales contra los despidos derivados del despido colectivo", op. cit., p. 783; BODAS MARTÍN, R., "Modificaciones de la Ley 36/2011, de 10 de octubre, reguladora de la jurisdicción social, producidas por la Ley 3/2012, de 6 de julio", op. cit., p. 497; y STS (Social) de 2 de julio de 2001 (Rec. 3815/2000) sobre la noción de "ámbito inferior al de una comunidad autónoma".

${ }^{26}$ Sobre ello, vid. PRECIADO DOMÈNECH, C. H., El nuevo proceso de despido colectivo en la Ley 3/2012, de 6 de julio, op. cit., p. 7 y 23; y BODAS MARTÍN, R., "Modificaciones de la Ley 36/2011, de 10 de octubre, reguladora de la jurisdicción social, producidas por la Ley 3/2012, de 6 de julio", op. cit., p. 499. Sobre la competencia de la Audiencia Nacional, véase la STSJ de Cataluña (Social) de 25 de septiembre de 2012 (Proc. 31/2012), sobre la extensión de los efectos del despido colectivo a un "ámbito superior al de una comunidad autónoma".

${ }^{27}$ Así, GOERLICH PESET, J. M., "La extinción del contrato de trabajo en la reforma de 2012: la culminación de una larga evolución", op. cit., p. 356.

${ }^{28}$ Así lo señala TASCÓN LÓPEZ, Rodrigo, "La impugnación del despido colectivo tras la reforma laboral: el Derecho del Trabajo en su laberinto", op. cit., p. 22, quien cree que el objetivo es la celeridad procesal y conseguir resoluciones homogéneas. Algunos autores, no obstante, han criticado la atribución de competencia a los TSJ, como MOLERO MARAÑÓN, M. L., "La nueva modalidad procesal de impugnación judicial del despido colectivo", op. cit., p. 6, que considera que ello quiebra el principio de
} 


\section{Contenido de la sentencia de impugnación del despido colectivo.}

El art. 124.11 LRJS regula el contenido de la sentencia de impugnación del despido colectivo en su modalidad colectiva, señalando que la misma podrá declarar el carácter ajustado a derecho, el carácter no ajustado a derecho, o el carácter nulo de la decisión empresarial extintiva.

\subsection{Declaración del carácter ajustado a derecho de la decisión extintiva.}

La sentencia declarará el carácter ajustado a derecho de la decisión extintiva cuando, habiéndose cumplido las formalidades del art. 51.2 ET, hayan quedado acreditadas las causas justificadoras del despido. Por lo tanto, tres aspectos son los relevantes en este punto: acreditar la regularidad del período de consultas, acreditar la regularidad de la entrega de la documentación pertinente, y acreditar la concurrencia de las causas invocadas. ${ }^{29}$

\subsection{Declaración del carácter no ajustado a derecho de la decisión extintiva.}

La sentencia declarará el carácter no ajustado a derecho de la decisión empresarial cuando, habiendo respetado las formalidades del art. 51.2 ET y no concurriendo vulneración de derechos fundamentales o discriminaciones ni ninguna causa que pudiera motivar la declaración de nulidad, el empresario no haya acreditado la concurrencia de la causa alegada. ${ }^{30}$

$\mathrm{Al}$ respecto, es interesante citar la STSJ de Andalucía/Sevilla (Social) de 20 de marzo de 2013 (Proc. 11/2012), que, a pesar de apreciar incumplimiento del deber de negociar de buena fe por parte del empresario, declara el carácter no ajustado a derecho de la decisión extintiva. En el supuesto enjuiciado, la empresa facilitó a la representación de los trabajadores un listado nominal de trabajadores afectados por el despido colectivo que difería de los criterios de selección que el empresario había comunicado en el escrito de inicio del procedimiento y en la memoria explicativa. Dicha infracción del deber de negociar de buena fe debiera conllevar la nulidad del procedimiento de despido colectivo, pero a pesar de ello, el tribunal declara, en cambio, el carácter no ajustado a derecho de la decisión, pues aprecia que ha habido negociación, se ha reducido el número de afectados y se han adoptado medidas para atenuar los efectos de los despidos, como un plan de recolocación y de formación. Por ello, el tribunal considera que la infracción del deber de buena fe es sólo parcial, en uno de los aspectos del procedimiento, pero no afecta a su conjunto.

\footnotetext{
"correspondencia entre la circunscripción a que alcanza el órgano judicial competente con el ámbito territorial de la controversia".

${ }^{29}$ Sobre el despido ajustado a derecho, véase SEMPERE NAVARRO, Antonio Vicente, "El proceso de impugnación del despido colectivo: la calificación del despido colectivo en la sentencia", en: GODINO REYES, Martín (dir.), Tratado de despido colectivo, València, Tirant lo Blanch, 2016, p. 689-694.

${ }^{30}$ Sobre el despido no ajustado a derecho, véase SEMPERE NAVARRO, A. V., "El proceso de impugnación del despido colectivo: la calificación del despido colectivo en la sentencia", op. cit., p. 695698.
} 
Ahora bien, dicha sentencia fue anulada y casada por la STS (Social) de 25 de junio de 2014 (Rec. 198/2013), que precisamente consideró que las circunstancias mencionadas (existencia de negociación, reducción del número de afectados, adopción de medidas paliativas) demuestran que no se incumplió el deber de negociar de buena fe, por lo que declara el carácter ajustado a derecho del despido.

\subsection{Declaración de nulidad de la decisión extintiva.}

La sentencia declarará la nulidad del procedimiento de despido cuando no se haya respetado el procedimiento del art. 51.2 ET o cuando la medida se haya adoptado con vulneración de los derechos fundamentales y libertades públicas de los trabajadores. ${ }^{31}$

Por lo tanto, el precepto agrupa las causas de nulidad en tres categorías:

- No haber realizado el período de consultas (art. 51.2 ET).

- No haber entregado la documentación prevista en el art. 51.2 ET.

- Vulneración de los derechos fundamentales y libertades públicas del trabajador.

La configuración de las causas de nulidad, con especial énfasis en las cuestiones procedimentales del art. 51.2 ET (período de consultas y documentación), muestra la importancia que tiene el procedimiento en el despido colectivo, y en particular la realización del período de consultas y la aportación de la documentación e información pertinente a los representantes de los trabajadores.

Ahora bien, no cualquier defecto procedimental debe conducir a la declaración de nulidad del despido. De hecho, el propio art. 124.11 LRJS señala que la nulidad se declarará "cuando el empresario no haya realizado las consultas o entregado la documentación prevista en el art. 51.2 ET”, por lo que únicamente conducirá a la nulidad el incumplimiento del deber de abrir y llevar a cabo un período de consultas, o el incumplimiento del principio de plenitud informativa. La referencia a la documentación fue introducida por la Ley 3/2012.

Así, respecto del resto de defectos procedimentales, habrá que analizar su trascendencia en cuanto a que se haya imposibilitado negociar y alcanzar un acuerdo. La nulidad sólo es predicable de los defectos formales que impliquen indefensión para los representantes de los trabajadores, ya que otra interpretación excesivamente formalista podría llevar a la declaración de nulidad de casi cualquier procedimiento de despido colectivo en el que haya habido meras omisiones formales que no hayan afectado al derecho de los representantes a negociar con vistas a alcanzar un acuerdo. ${ }^{32}$

\footnotetext{
${ }^{31}$ Sobre la nulidad del despido colectivo, véase SEMPERE NAVARRO, A. V., "El proceso de impugnación del despido colectivo: la calificación del despido colectivo en la sentencia", op. cit., p. 698-719.

${ }^{32}$ Sobre esta cuestión, BLASCO PELLICER, Á., La extinción del contrato de trabajo en la reforma laboral de 2012, op. cit., p. 110. La SAN (Social) de 28 de septiembre de 2012 (Proc. 152/2012), confirmada por la STS (Social) de 18 de febrero de 2014 (Rec. 96/2013), señala que sólo conducen a la nulidad las vulneraciones del período de consultas de carácter material y que hayan ocasionado una merma a las garantías y derechos de los trabajadores y sus representantes, pero no las vulneraciones meramente formales, y ello precisamente porque el objetivo de la ley y de las formalidades allí reguladas es el de proteger las garantías de los trabajadores y sus representantes. Por su parte, MOLERO MARAÑ́́N, M. L.,
} 


\section{Aportación insuficiente o defectuosa de la documentación pertinente. ${ }^{33}$}

Como ha señalado la STS (Social) de 19 de noviembre de 2013 (Rec. 78/2013), la falta de aportación de la documentación e información pertinente provoca en los representantes de los trabajadores una situación de desinformación que afecta a la "existencia de un verdadero período de consultas", de modo que cabe afirmarse que, sin la documentación e información pertinente, no hay período de consultas propiamente dicho. ${ }^{34}$

\subsection{Aportación de la documentación legal y reglamentaria.}

En cuanto a la documentación que se debe aportar, hay que estar a la que señala el art. 51.2 ET y también a la que recoge el RPDC, ya que el Estatuto de los Trabajadores hace una remisión expresa al mismo. ${ }^{35}$

Antes de la aprobación del RPDC por el Real Decreto 1483/2012, alguna sentencia aislada entendió que la nulidad la determinaba la falta, únicamente, de la documentación referida en el art. 51.2 ET, y no aquella que pudiera ser objeto de desarrollo reglamentario. ${ }^{36}$ No obstante, la Ley 3/2012 modificó el art. 51.2 ET, introduciendo la referencia al desarrollo reglamentario, extendiendo la nulidad a los incumplimientos documentales contenidos en el posterior RPDC aprobado por el Real Decreto $1483 / 2012 .^{37}$

Un sector doctrinal ha criticado esta remisión al Reglamento efectuada por el art. 51.2 ET, pues supone dejar en manos gubernamentales el alcance de la presente causa de nulidad relativa al cumplimiento de las obligaciones documentales, de modo que una mayor o menor concreción reglamentaria sobre los requisitos de documentación va a poder incidir en la causa de nulidad. ${ }^{38}$

El propio Tribunal Supremo, en STS (Social) de 25 de febrero de 2015 (Rec. 74/2014), ha señalado que "la enumeración de documentos que hace la norma reglamentaria no tiene valor ad solemnitatem, y no toda ausencia documental por fuerza ha de llevar a la referida declaración de nulidad". ${ }^{39}$ En materia de criterios de selección de los trabajadores

\footnotetext{
"La nueva modalidad procesal de impugnación judicial del despido colectivo", op. cit., p. 32, lo expresa señalando que sólo es motivo de impugnación el "incumplimiento total" del período de consultas.

33 Sobre esta cuestión en mayor profundidad, véase PUEBLA PINILLA, Ana de la, "Exigencias documentales en el despido colectivo: del RDL 3/2012 a la Ley 3/2012. STSJ Madrid 30 mayo 2012", Aranzadi Social, núm. 7, 2012; y ARASTEY SAHÚN, María Lourdes, "El período de consultas: la solicitud y entrega de información y documentación no prevista legalmente”, en: GODINO REYES, Martín (dir.), Tratado de despido colectivo, València, Tirant lo Blanch, 2016, p. 290 y ss.

${ }^{34}$ Así lo señala ARASTEY SAHÚN, M. L., "El período de consultas: la solicitud y entrega de información y documentación no prevista legalmente", op. cit., p. 290.

35 Así lo considera BLASCO PELLICER, Á., La extinción del contrato de trabajo en la reforma laboral de 2012, op. cit., p. 110.

${ }^{36}$ En este sentido, la STSJ de Galicia (Social) de 19 de julio de 2012 (Rec. 8/2012) señala que "la nulidad de la decisión extintiva sólo cabe cuando se incumplen las exigencias contenidas en el art. 51 ET."

37 Así lo ha señalado claramente PUEBLA PINILLA, A. de la, "Exigencias documentales en el despido colectivo: del RDL 3/2012 a la Ley 3/2012. STSJ Madrid 30 mayo 2012”, op. cit., p. 4-5.

${ }^{38}$ En este sentido, PRECIADO DOMÈNECH, C. H., El nuevo proceso de despido colectivo en la Ley 3/2012, de 6 de julio, op. cit., p. 56.

39 También sobre esta cuestión, SEMPERE NAVARRO, A. V., "El proceso de impugnación del despido colectivo: la calificación del despido colectivo en la sentencia”, op. cit., p. 709.
} 
afectados, esta consideración es de escasa virtualidad, atendiendo al hecho de que, en relación a los mismos, no hay ninguna disposición reglamentaria que exija la aportación de nuevos documentos no previstos legalmente. El RPDC tan solo matiza y desarrolla las exigencias contenidas en el art. 51.2 ET, y añade otros documentos que nada tienen que ver con los criterios de selección (documentación contable, informes técnicos, etc.). A ellos habrá que aplicar las consideraciones ya señaladas por el TS sobre su carácter no siempre trascendente.

Algún pronunciamiento en sede de TSJ se ha pronunciado al respecto. Así, la STSJ de Castilla y León/Valladolid (Social) de 5 de noviembre de 2015 (Proc. 2/2015) señala que "el listado de documentación mencionado en la norma reglamentaria goza de presunción de necesidad para la negociación, pero esa presunción puede ser desvirtuada, por ejemplo, cuando, no habiendo sido entregada, los trabajadores no la reclaman a lo largo del período de consultas". ${ }^{40}$ Ello implica, en definitiva, que la documentación cuya aportación sí que reviste especial trascendencia es la enumerada en el art. 51.2 ET.

\subsection{Aportación de los extremos del art. 51.2 ET: interpretación finalista.}

La ausencia de alguno de los extremos del art. 51.2 ET determina la calificación de nulidad del despido colectivo. Por lo tanto, si el escrito de inicio del período de consultas no contiene las causas del despido, el número y clasificación profesional de los trabajadores afectados, el número y clasificación profesional de los trabajadores empleados habitualmente en el último año, el período previsto para realizar los despidos, o los criterios de selección a tener en cuenta en la designación de los afectados, la calificación que corresponde al despido colectivo es la de nulidad. Además de la constancia de los documentos exigidos por la norma, también habrá que estar al hecho de que dichos documentos reúnan los requisitos formales que requiere la norma, de modo que la exigencia pueda entenderse cumplida en modo suficiente.

Las anteriores aseveraciones se derivan de la interpretación literal del art. 51.2 ET y del art. 124.2 LRJS. Ahora bien, hay algunas matizaciones a realizar. El Tribunal Supremo ha fijado una interpretación finalista sobre los requisitos documentales en el despido colectivo, por lo que "no todo incumplimiento de las previsiones contenidas en aquel precepto puede alcanzar la consecuencia de nulidad que se pueda desprender del art. 124 LRJS, sino tan sólo aquella que sea trascendente a los efectos de una negociación adecuadamente informada". ${ }^{41}$ En consecuencia, "de tan drástica consecuencia [la

\footnotetext{
${ }^{40}$ Véase ARASTEY SAHÚN, M. L., "El período de consultas: la solicitud y entrega de información y documentación no prevista legalmente", op. cit., p. 291.

${ }^{41}$ Véase STS (Social) de 20 de marzo de 2013 (Rec. 81/2012), y STS (Social) de 27 de mayo de 2013 (Rec. 78/2012). También, ARASTEY SAHÚN, M. L., "El período de consultas: la solicitud y entrega de información y documentación no prevista legalmente", op. cit., p. 289-291, quien señala que la STS (Social) de 20 de marzo de 2013 (Rec. 81/2012) fue la primera sentencia dictada por el Tribunal Supremo referida a un despido colectivo tras la aprobación del Real Decreto-ley 3/2012. En materia de apreciación finalista del cumplimiento de las obligaciones documentales durante el período de consulta, se han pronunciado en un sentido similar las SSTS (Social) de 26 de marzo de 2014 (Rec. 158/2013); de 7 de julio de 2014 (Rec. 32/2014); de 20 de noviembre de 2014 (Rec. 114/2014); de 3 de diciembre de 2014 (Rec. 201/2013); de 25 
nulidad] han de excluirse aquellos documentos que se revelen intranscendentes a los efectos que la norma persigue". ${ }^{42}$ Dicha finalidad no es sino "la de que los representantes de los trabajadores tengan una información suficientemente expresiva de las causas de los despidos, de suerte que puedan afrontar el período de consultas adecuadamente". ${ }^{43}$

De este modo, los deberes de información y documentación tienen un carácter "instrumental" al cumplimiento de su finalidad, que es la de proporcionar a la representación de los trabajadores la información relevante y suficiente para poder entablar una negociación efectiva durante el período de consultas, como han señalado las SSTS (Social) de 21 de mayo de 2014 (Rec. 182/2013), y de 20 de noviembre de 2014 (Rec. 114/2014). ${ }^{44}$

En definitiva, dicha interpretación implica la posibilidad de establecer una gradación sobre el nivel de incumplimiento de las obligaciones empresariales de información y documentación, lo que determina la posibilidad de que ello suponga distintas consecuencias por lo que respecta a la calificación del despido, de suerte que sólo aquellos incumplimientos que resulten trascendentes determinarán la nulidad del despido. ${ }^{45}$

En cuanto a la documentación, no hay duda de que la falta de aportación de la memoria explicativa o su insuficiencia manifiesta determina la nulidad de la decisión extintiva. En este sentido, numerosas sentencias han apreciado la nulidad por la "notable insuficiencia" de la memoria explicativa, que se limitaba a meras alegaciones y una descripción general de la situación de la empresa. ${ }^{46}$

Por lo que respecta a los concretos extremos del art. 51.2 ET, y en particular los relativos al número y clasificación profesional de los afectados, los empleados habitualmente en el último año, el período previsto para efectuar los despidos, así como los criterios de selección de los afectados, habrá que estar al caso concreto y tener presente la interpretación finalista e instrumental que de las obligaciones documentales han realizado los tribunales.

\subsection{No aportación del desglose de los afectados por clasificación profesional y/o por centros, provincia o comunidad autónoma.}

\footnotetext{
de marzo de 2015 (Rec. 295/2014); de 16 de junio de 2015 (Rec. 273/2014); de 29 de septiembre de 2015 (Rec. 1/2015); de 20 de octubre de 2015 (Rec. 181/2014); y de 24 de noviembre de 2015 (Rec. 86/2015).

${ }^{42}$ STS (Social) de 25 de febrero de 2015 (Rec. 74/2014).

${ }^{43}$ STS (Social) de 25 de junio de 2014 (Rec. 273/2013).

${ }^{44}$ Sobre el carácter instrumental de la aportación de documentación en el despido colectivo, véase en la doctrina BLASCO PELLICER, Á., "El proceso de impugnación del despido colectivo: el objeto del procedimiento. Las pretensiones posibles", op. cit., p. 569; SEMPERE NAVARRO, A. V., "El proceso de impugnación del despido colectivo: la calificación del despido colectivo en la sentencia", op. cit., p. 709; y SÁEZ LARA, Carmen, Reestructuraciones empresariales y despidos colectivos, op. cit., p. 267-271.

${ }^{45}$ En la doctrina, SEMPERE NAVARRO, A. V., "El proceso de impugnación del despido colectivo: la calificación del despido colectivo en la sentencia", op. cit., p. 709, señala que la posición del TS en estos supuestos responde más bien a razones lógicas que a la estricta literalidad impuesta por el legislador, lo cual conecta con lo ya comentado: según el tenor de los preceptos legales, la no aportación de alguno de los extremos del art. 51.2 ET debiera llevar aparejada la declaración de nulidad.

${ }^{46}$ Véase PRECIADO DOMÈNECH, C. H., El nuevo proceso de despido colectivo en la Ley 3/2012, de 6 de julio, op. cit., p. 64; y STSJ de Madrid (Social) de 30 de mayo de 2012 (Proc. 17/2012).
} 
Se han planteado numerosos interrogantes en torno al extremo relativo al número y clasificación profesional de los trabajadores afectados. Así, pueden encontrarse procedimientos de despido colectivo en los que la empresa no informó de la clasificación profesional de los trabajadores afectados. Del mismo modo, ello conecta con la cuestión del desglose de los afectados por centros de trabajo, provincia y/o comunidad autónoma cuando corresponda, que es un requisito que viene establecido por vía reglamentaria en el RPRC. Según la interpretación finalista e instrumental proporcionada por los tribunales, y en función de las circunstancias en que se desenvuelva el período de consultas, la falta de alguno de los elementos señalados (clasificación profesional o desglose territorial de los afectados) no necesariamente lleva aparejada la declaración de nulidad del despido colectivo.

Ejemplificativo es el supuesto abordado en la STS (Social) de 25 de junio de 2014 (Rec. 273/2013), que confirma la SAN (Social) de 10 de junio de 2013 (Proc. 112/2013), en el que la empresa había designado a toda la plantilla como potencialmente afectada por el despido y había omitido la información relativa al desglose de la clasificación profesional, el desglose por centros de trabajo, y provincia o comunidad autónoma. El TS rechazó la calificación de nulidad, señalando que "si bien la empresa inicialmente incluía a toda la plantilla, afectándola de modo genérico, partía de una justificación -la incertidumbre sobre la continuidad de los trabajos- que fue asumida sin dificultad por el banco social, por cuanto, pese a la inicial imprecisión, permitió que se desarrollara el proceso negociador y se produjera la sucesiva concreción de los afectados", llegándose incluso a alcanzar un acuerdo. ${ }^{47}$

En definitiva, a pesar de no aportar la clasificación profesional de los trabajadores afectados, se entiende que la información global aportada por el empresario cumple su finalidad cuando el empresario sí que aporta otros datos, como puede ser el número de afectados, y también los criterios de selección para su designación, pues permite a los representantes entablar una negociación.

\subsection{Aportación suficiente de los criterios de selección: nivel de concreción.}

La aportación del extremo documental referido a los criterios de selección debe cumplir, con carácter general, con los caracteres de objetividad, coherencia, suficiencia o precisión, proporcionalidad o adecuación al fin perseguido, así como respeto a los derechos fundamentales. ${ }^{48}$ Ahora bien, la interpretación finalista o instrumental proporcionada por los tribunales, debe servir para "analizar el alcance de los defectos en la expresión de los criterios” de selección, en términos expresados por la STS (Social) de 25 de junio de 2014 (Rec. 273/2013). En otras palabras, a la hora de determinar el nivel de suficiencia de los criterios de selección a efectos de una eventual declaración de

\footnotetext{
${ }^{47}$ En cambio, la STSJ de Cataluña (Social) de 23 de mayo de 2012 (Proc. 10/2012) declara la nulidad del despido colectivo por falta de aportación de la clasificación profesional y por aportar criterios de selección genéricos.

48 Véase ROQUETA BUJ, Remedios, La selección de los trabajadores afectados por los despidos colectivos, València, Tirant lo Blanch, 2015, p. 55; y CERVERA SOTO, Teresa, CID BABARRO, Carlos, El despido colectivo: claves prácticas y análisis jurisprudencial, Valladolid, Lex Nova, 2016, p. 163 y ss.
} 
nulidad del despido colectivo, habrá que tener presente hasta qué punto el nivel de concreción de los criterios influye en el correcto desarrollo del período de consultas. Dicho análisis lo realizan los tribunales valorando la exigencia de aportar los criterios de selección "en relación con las circunstancias concretas sobre las que se proyecta en cada caso". 49

En materia de suficiencia de la documentación aportada relativa a los criterios de selección, hay numerosos pronunciamientos del Tribunal Supremo. ${ }^{50}$ La STS (Social) de 22 de mayo de 2014 (Rec. 17/2014) aplica el criterio flexible y finalista respecto del nivel de suficiencia de los criterios de selección expresados por el empresario al inicio y durante el período de consultas. Así, el TS reconoce que la información que facilitó la empresa "podría haber sido más concreta", pero valora diversas circunstancias: que la empresa tenía "sólo" 32 trabajadores; que los representantes no formularon ninguna objeción al respecto; y que consta que los mismos tuvieron "conocimiento" de los trabajadores afectados y excluidos, así como de los motivos de inclusión o exclusión de los mismos en el despido colectivo, es decir, de los criterios de selección. En definitiva, el TS considera que no podía considerarse que la información y documentación fuera defectuosa.

Por su parte, la STS (Social) de 18 de febrero de 2014 (Rec. 74/2013) hace referencia a la necesidad de atender a las circunstancias concretas del caso, y señala que las particularidades específicas de la empresa ${ }^{51}$ hacían difícil una mayor concreción de los criterios, cosa que sí aconteció a lo largo de la negociación en el período de consultas. ${ }^{52}$

En la STS (Social) de 20 de octubre de 2015 (Rec. 172/2014), asunto Tragsa, se señala que la reducción del número de afectados en la decisión final con respecto a la propuesta inicialmente planteada, no puede dar lugar a "exigir mayor documentación sobre los criterios y el método de selección", cuando ello ya ha sido explicitado durante el período de consultas. ${ }^{53}$

\footnotetext{
${ }^{49}$ STS (Social) de 25 de junio de 2014 (Rec. 273/2013) y STS (Social) de 18 de febrero de 2014 (Rec. 74/2013).

${ }^{50}$ Véanse las SSTS (Social) de 18 de febrero de 2014 (Rec. 74/2013); de 20 de mayo de 2014 (Rec. 276/2013); de 22 de mayo de 2014 (Rec. 17/2014); de 25 de junio de 2014 (Rec. 273/2013); de 17 de julio de 2014 (Rec. 32/2014); de 18 de julio de 2014 (Rec. 303/2013); de 23 de septiembre de 2014 (Rec. 231/2013); de 25 de marzo de 2015 (Rec. 295/2014); de 24 de marzo de 2015 (Rec. 217/2014); y de 20 de octubre de 2015 (Rec. 181/2014).

${ }^{51}$ Instituto Técnico Agronómico Provincial S.A.

${ }^{52}$ Sobre el nivel de concreción de los criterios y las circunstancias concretas del caso, véase SÁEZ LARA, Carmen, Reestructuraciones empresariales y despidos colectivos, op. cit., p. 271.

${ }^{53}$ Véase ARASTEY SAHÚN, M. L., "El período de consultas: la solicitud y entrega de información y documentación no prevista legalmente", op. cit., p. 301-302. La STS (Social) de 20 de octubre de 2015 (Rec. 172/2014) señala: "aunque el número de afectados en ese estudio [que proporcionó la empresa a la representación de los trabajadores] era inferior al finalmente fijado en la decisión extintiva, no es menos cierto que también resultó ser notablemente menor que el inicialmente propuesto", por lo que se señala que "razonablemente no se puede acusar de carente de explicación la cifra que media entre dos explicaciones técnicas, la máxima de la propuesta inicial y la mínima de la propuesta de acuerdo; y aún menos para deducir de tal pretendido defecto formal -con rigor que rechazamos- que la decisión adoptada es nula."
} 
En relación a esta cuestión, la empresa no puede aumentar el número de trabajadores afectados, pues ese aumento supondría la propuesta de una nueva medida respecto de la cual no habría habido período de consultas. ${ }^{54}$ En cambio, nada obsta a que, de acuerdo con el desarrollo del período de consultas y con los motivos alegados al inicio del procedimiento, el empresario adopte finalmente una decisión de despido que mejore los planes inicialmente propuestos, pues ello redunda en beneficio de los trabajadores, sin necesidad de aportar documentación complementaria. En este sentido, la propia STS (Social) de 20 de octubre de 2015 (Rec. 172/2014) lo señala expresamente, al afirmar que "la decisión empresarial puede atender -al menos en parte- las pretensiones de la parte social y mejorar numéricamente -reduciéndolo- el número de trabajadores afectados, y, ello no implica que tales mejoras deban ir acompañadas de memoria explicativa o informe técnico algunos". En consecuencia, una reducción del número de afectados no necesariamente implica la necesidad de aportar documentación adicional en torno a los criterios de selección. ${ }^{55}$

Los citados pronunciamientos judiciales dan pie a analizar los distintos parámetros a los que acude el Tribunal Supremo a la hora de establecer el nivel de insuficiencia o irregularidad informativa y/o documental a efectos de nulidad del despido colectivo. Dichos parámetros a valorar son los siguientes:

- Las hipotéticas irregularidades documentales o informativas deben analizarse a la luz del criterio finalista, según el cual sólo merecen la calificación de nulidad aquellas irregularidades en materia documental o informativa que sean trascendentes a efectos de conseguir el fin del período de consultas, que no es otro que permitir que los representantes de los trabajadores estén pertinentemente informados a fin de negociar con vistas a alcanzar un acuerdo.

- Las exigencias documentales contenidas en disposiciones reglamentarias, como el RPDC, no tienen carácter ad solemnitatem, por lo que sólo serán exigibles aquellos documentos que sean trascendentes.

- El órgano juzgador, para valorar la posible nulidad, debe tener presentes las circunstancias concretas del caso en el que se ha planteado la supuesta irregularidad, procediendo a un análisis casuístico, sin ser posible extraer conclusiones generales con carácter apriorístico. Dentro del análisis caso por caso que debe realizar el órgano juzgador, son varias las circunstancias que puede tener presentes:

\footnotetext{
${ }^{54}$ Así lo aprecia GOERLICH PESET, José María, "Desarrollo y contenido de las consultas”, en: AA.VV., Los períodos de consultas, Colección Informes y Estudios, Serie Relaciones Laborales núm. 104, Madrid, Ministerio de Empleo y Seguridad Social, 2014, p. 126. La SAN (Social) de 29 de julio de 2014 (Proc. 145/2014) declara la nulidad del procedimiento de despido colectivo porque en la decisión final la empresa incrementó notablemente el número de afectados con respecto a la comunicación inicial. Se trata de una nulidad por actualización in peius de la propuesta de despido, ya que, sobre el exceso de extinciones previstas, no se ha realizado período de consultas alguno.

${ }^{55}$ No obstante, hacer alguna matización a esta cuestión, y es la relativa a que dicha mejora final adoptada por el empresario debe guardar cierta coherencia con los motivos de despido indicados al inicio del período de consultas y con las propuestas y contrapropuestas discutidas en el período de consultas.
} 
- El volumen de la plantilla. El TS considera que no es equiparable el despido colectivo llevado a cabo en una plantilla con un elevado número de trabajadores que en una plantilla reducida. En este sentido, en empresas con una plantilla reducida se deduce que para los representantes es más fácil inferir lógicamente qué trabajadores van a ser afectados y cómo se aplican los criterios de selección. De hecho, es habitual que, en empresas con plantillas reducidas, los representantes conozcan directamente qué trabajadores van a resultar afectados, con lo que se cumple el objetivo por el que la norma impone al empresario el deber de informar sobre los criterios de selección. Por otro lado, puede darse la paradoja de que se permita la expresión genérica de los criterios de selección en empresas con grandes plantillas, debido a la complejidad de la misma.

- El efectivo conocimiento por parte de los representantes de los trabajadores de qué trabajadores van a ser afectados o cuáles son los motivos o criterios para incluirlos. En este sentido, el efectivo conocimiento por parte de los representantes cumple la finalidad de la expresión de los criterios de selección, por lo que habrá que tenerse presente ante una eventual pretensión de nulidad. Carecería de toda lógica sancionar con la nulidad un despido colectivo por falta de expresión de un extremo informativo cuando los representantes de los trabajadores sí que tenían efectivo conocimiento del mismo.

- La progresiva concreción de la información a lo largo del período de consultas. Si la información aportada inicialmente se completa a lo largo del período de consultas, se cumple también con la finalidad establecida, especialmente en procedimientos complejos en los que sea difícil concretar toda la información desde el inicio.

- La final adopción de un acuerdo. Se trata de la circunstancia que en modo más evidente permite determinar que no se ha impedido que el período de consultas cumpliera su finalidad. Si la supuesta falta de información no impide que finalmente se alcance un acuerdo válido, no tendría sentido sancionar todo el procedimiento con la declaración de nulidad.

- Inexistencia de alegación alguna por parte de los representantes de los trabajadores en el momento de darse la pretendida insuficiencia informativa o documental, o aceptación táctica por los propios actos. Reviste especial importancia la actitud de la representación de los trabajadores durante el período de consultas. Se trata de otro de los criterios valorados por los tribunales, y que se refiere al hecho de que los representantes de los trabajadores no aleguen la pretendida irregularidad documental en el momento pertinente mientras se lleva a cabo el período de consultas. Si bien no es una circunstancia determinante que impida alegar la nulidad en un posterior proceso jurisdiccional, sí que es cierto 
que los tribunales lo han tenido muy en cuenta a la hora de valorar el grado de afectación de la irregularidad documental respecto del desarrollo del período de consultas. En este sentido, la actitud de los representantes en el período de consultas, que tuvieron ocasión de alegar la irregularidad documental, y no lo hicieron, es una circunstancia que contribuye a que el órgano juzgador se cree la convicción de que la pretendida irregularidad no ha impedido que el período de consultas cumpliera los fines que la ley le atribuye.

El Tribunal Supremo ha asumido plenamente el parámetro interpretativo mencionado. Así, la STS (Social) de 20 de octubre de 2015 (Rec. 172/2014) señala que "la exigible coherencia entre la fase de consultas y la reclamación judicial es consecuencia obligada de la buena fe y componente determinante para la apreciación de defectos en el período de consultas, como una manifestación en definitiva de la doctrina de los propios actos, que impone la vinculación del autor de una declaración de voluntad -de significación jurídica inequívoca- al sentido objetivo de la misma y a la imposibilidad de adoptar después un comportamiento que contradiga aquélla". 56

Finalmente, otra cuestión a la que se han referido los tribunales es la declaración de nulidad únicamente en los supuestos en que haya una ausencia absoluta de criterios de selección, es decir, que no se hayan aportado en absoluto. La STS (Social) de 26 de marzo de 2014 (Rec. 158/2013), asunto Telemadrid, ha señalado que únicamente la falta de aportación de los criterios de selección da lugar a la nulidad del despido colectivo, pero no su mera insuficiencia o irregularidad. ${ }^{57}$ Ahora bien, dicha rotunda afirmación debe conectarse con otros pronunciamientos del Tribunal Supremo en que analiza el nivel de concreción y suficiencia de los criterios de selección conforme a las circunstancias concretas del caso en cuestión. Tal es el caso de la STS (Social) de 20 de octubre de 2015 (Rec. 172/2014), asunto Tragsa, en el que una inicial imprecisión de los criterios queda salvada por una serie de circunstancias concurrentes y ya mencionadas, como la final consecución del acuerdo. ${ }^{58}$

Debe notarse que tanto en el asunto Telemadrid como en el asunto Tragsa, se trata de empresas de gran dimensión en las que precisar inicialmente los criterios de selección

\footnotetext{
${ }^{56}$ En los mismos términos, las SSTS (Social) de 17 de julio de 2014 (Rec. 32/2014), y de 16 de junio de 2015 (Rec. 273/2014).

${ }^{57}$ STS (Social) de 26 de marzo de 2014 (Rec. 158/2013), asunto Telemadrid: "Ello evidencia la inexistencia de la causa de nulidad con base a la irregularidad de insuficiencia de criterios en la designación de los trabajadores afectados [arts. 51.2 ET, 124.9 LRJS y 3.1 e) RPDC], pues lo que exige la norma es la aportación de los criterios tenidos en cuenta para la designación de los trabajadores afectados, y solo la ausencia de tal aportación de criterios daría lugar a la nulidad del despido, lo cual no concurre en el caso en que constan los criterios con independencia de la valoración que pueda hacerse de los mismos."

58 STS (Social) de 20 de octubre de 2015 (Rec. 172/2014), asunto Tragsa: "No cabe la menor duda -ya lo hemos adelantado- de que los «criterios de selección» antes referidos no pueden calificarse como «detalladamente precisos». Pero tampoco es menos cierto: [...]" En ese punto, el TS señala una serie de circunstancias que permiten apreciar el cumplimiento de la obligación documental, ya mencionadas.
} 
supone una tarea de gran complejidad. Ahora bien, la mera aportación de los criterios de selección no salva el procedimiento de despido colectivo de la declaración de nulidad en cualquier circunstancia, pues hay que estar a otras posibles causas de nulidad, como principalmente la vulneración de los derechos fundamentales y libertades públicas del trabajador (por ejemplo, en supuestos de criterios de selección discriminatorios). También darían lugar a la declaración de nulidad aquellos criterios inicialmente genéricos si no se dan las circunstancias particulares que señala el TS en el asunto Telemadrid o en el asunto Tragsa; es decir, las circunstancias relativas a una posterior concreción de los criterios durante el período de consultas, el asentimiento tácito de los representantes de los trabajadores, o la final consecución de un acuerdo válido.

En cualquier caso, y a pesar de los parámetros que permiten una interpretación flexible de la exigencia de aportar los criterios de selección de los afectados, la STS (Social) de 18 de julio de 2014 (Rec. 303/2013) señala con toda claridad que la aportación de los criterios de selección por parte del empresario al inicio del período de consultas constituye "una exigencia formal ineludible, cuyo incumplimiento debe comportar la nulidad del despido al impedir que el período de consultas cumpla con su finalidad". Los criterios de selección "deben permitir establecer la oportuna relación de causalidad entre las medidas y la afectación concreta de los trabajadores", por lo que "una real ausencia de criterios de selección devaluará la negociación en el período de consultas, en cuanto que los representantes de los trabajadores no podrán ofertar o contraofertar a las medidas empresariales, haciendo inútil el objetivo finalístico del período de consultas y el posterior y oportuno control judicial".

Como conclusión, la nulidad se reserva principalmente para aquellos supuestos en que haya una ausencia absoluta de criterios, o para los supuestos de aportación defectuosa en que, tras el análisis de las circunstancias del caso, dichos defectos hayan tenido repercusión negativa en la efectividad del período de consultas. ${ }^{59} \mathrm{Si}$ la irregularidad o imprecisión de los criterios no ha obstaculizado el correcto desarrollo del período de consultas, no procede declarar la nulidad. Se trata de una interpretación que rechaza posturas formalistas o rigoristas que sancionarían con la nulidad un despido por la mera falta de alguna de las exigencias documentales, lo cual no se corresponde con la doctrina del TS de valorar la "verdadera realidad" de la negociación durante el período de consultas, y no tanto la aportación de todos y cada uno de los documentos exigidos. ${ }^{60}$

\subsection{Aportación tardía de la documentación.}

\footnotetext{
${ }^{59}$ STS (Social) de 18 de julio de 2014 (Rec. 303/2013). ARASTEY SAHÚN, M. L., "El período de consultas: la solicitud y entrega de información y documentación no prevista legalmente", op. cit., p. 290, matiza que la interpretación finalista no desvirtúa la regla general según la cual la aportación de la documentación es obligatoria. Lo que implica la interpretación es que la regla general de nulidad en casos de incompleta aportación documental puede exceptuarse si se acredita que la información era intranscendente, o que se obtuvo a lo largo del período de consultas.

${ }^{60}$ En este sentido, STS (Social) de 25 de junio de 2014 (Rec. 273/2013).
} 
La impugnación de la aportación tardía de la documentación se analiza por los tribunales con los mismos parámetros acabados de señalar sobre la irregularidad en la aportación de la documentación, en general, y de los criterios de selección, en particular. Ello se traduce en atender al caso concreto, ${ }^{61}$ y valorar si los representantes obtuvieron la información pertinente que les permitiera negociar e incluso llegar, en su caso, a un acuerdo.

La STS (Social) de 18 de julio de 2014 (Rec. 303/2013) destaca que es importante que "desde el inicio mismo del procedimiento de despido colectivo, [los representantes] puedan disponer" de la información pertinente, y en especial de los criterios de selección. A continuación, señala: "la mera circunstancia de que no se aporte completa al inicio del periodo no vicia por sí solo el procedimiento de despido colectivo a no ser, como regla, que por la trascendencia de la misma o por el momento de su aportación dificultara o impidiera una adecuada negociación de buena fe en aras a que el periodo de consultas cumpla con su finalidad." Es decir, aplica a la aportación tardía de la documentación los mismos parámetros analizados sobre la aportación irregular de la misma.

En definitiva, si la omisión de alguno de dichos extremos se subsana a lo largo del período de consultas, de suerte que las partes puedan negociar con vistas a alcanzar un acuerdo, la decisión empresarial no podría ser calificada de nula, pues prima la interpretación finalista de los requisitos formales. Por ello, ante la falta inicial de alguno de los elementos documentales señalados en el art. 51.2 ET, posteriormente subsanada durante el período de consultas, permitiendo el conocimiento del mismo por parte de los representantes de los trabajadores y permitiendo la negociación, incluso llegando a alcanzar un acuerdo, en esos casos habría que atender a las circunstancias del caso concreto.

En este sentido, habrá que ver si el período de consultas ha podido cumplir con su finalidad, que no es otra que la de permitir la negociación y la posibilidad de alcanzar un acuerdo. En línea con ello, la STS (Social) de 21 de mayo de 2014 (Rec. 182/2013) rechaza la calificación de nulidad del despido colectivo cuando la aportación tardía de documentación no haya afectado al período de consultas perjudicando la efectiva negociación.

La interpretación flexible en torno a los deberes documentales viene avalada por el Tribunal de Justicia de la Unión Europea (TJUE). Así, la STJUE de 10 de septiembre de 2009, Akavan, asunto C-44/08 [ECLI:EU:C:2009:533], señala que, respecto al cumplimiento de los deberes documentales "es indispensable cierta flexibilidad, dado que, por una parte, dicha información puede llegar a estar disponible en diferentes momentos del proceso de consulta, lo que implica que el empresario tenga la posibilidad y la obligación de completarla durante dicho proceso". Y señala que "el objetivo de esta obligación del empresario es permitir a los representantes de los trabajadores participar en el proceso de consulta lo más completa y efectivamente posible, y, para ello, debe proporcionar hasta el último momento de la consulta cualquier nueva información pertinente".

\footnotetext{
${ }^{61}$ STS (Social) de 18 de febrero de 2014 (Rec. 74/2013).
} 
Se destacan unas expresiones, en tanto que el TJUE permite la aportación de documentación "hasta el último momento" del período de consultas, pero matiza que se refiere a cualquier "nueva" información pertinente, con lo que, al menos en ese aspecto, no parece respaldar la entrega tardía sin más de la documentación. Aunque sí que es relevante la primera frase del pronunciamiento, pues admite la flexibilidad y reconoce la existencia de "diferentes momentos" en el período de consultas, que es una sucesión de actos con intercambio de pareceres que no se produce en un momento instantáneo, sino que se prolonga durante un cierto período de tiempo.

\subsection{Obligaciones documentales: recapitulación.}

Las irregularidades en el cumplimiento de los deberes de información y consulta se convirtieron, tras la reforma laboral de 2012, en la principal fuente de conflictividad en materia de despidos colectivos, habiendo disparado la litigiosidad sobre ello, como señala la SAN (Social) de 13 de noviembre de 2015 (Proc. 257/2015), asunto Indra. ${ }^{62}$ Para la doctrina, la abundante litigiosidad en torno a la supuesta insuficiencia documental o informativa es la que ha hecho necesaria una interpretación no rigorista de la relevancia de la aportación de dichos documentos. ${ }^{63}$

Como conclusión, el Tribunal Supremo aplica el criterio de valorar si ha habido o no una real y efectiva negociación, de modo que, si la información que se ha facilitado y el momento en que se ha aportado permiten a los representantes de los trabajadores entablar una negociación, en ese caso las exigencias en materia de información y documentación se entenderán cumplidas.

\section{Vulneración de los derechos fundamentales y libertades públicas.}

Otro motivo de nulidad previsto en el art. 124.11 LRJS es el referido a que "la medida empresarial se haya efectuado en vulneración de derechos fundamentales y libertades públicas". ${ }^{64}$ En este punto, cuando la selección de los trabajadores despedidos se realice conforme a criterios que vulneran los derechos fundamentales, y en especial criterios que tengan carácter discriminatorio, el despido colectivo será calificado como nulo.

\footnotetext{
${ }^{62}$ Así lo pone de relieve ARASTEY SAHÚN, M. L., "El período de consultas: la solicitud y entrega de información y documentación no prevista legalmente", op. cit., p. 288; y también PUEBLA PINILLA, A. de la, "Las paradojas del despido colectivo tras la supresión de la autorización administrativa", op. cit., p. 138.

${ }^{63}$ Así lo señala MARTÍNEZ MORENO, Carolina, "La nulidad en el despido colectivo: causas y límites", en: AA.VV., Encuentro de magistrados de la Sala Cuarta del Tribunal Supremo con presidentes de las Salas de lo Social de los Tribunales Superiores de Justicia y de la Audiencia Nacional: La reforma laboral. Problemas sustantivos y procesales en su aplicación, Cuadernos Digitales de Formación, núm. 24, Madrid, Consejo General del Poder Judicial, 2013. Precisamente la SAN (Social) de 13 de noviembre de 2015 (Proc. 257/2015) abordaba la reclamación por parte del banco social de decenas de documentos, respecto de la cual señala el tribunal que "constituye claramente una mala práctica, que impide objetivamente que el período de consultas alcance sus fines", por lo que no resulta admisible exigir "en cascada" decenas de documentos, muchos de los cuales no existían y no eran transcendentes. Sobre esta cuestión, véase MERCADER UGUINA, Jesús Rafael, "El período de consultas: la intervención de la autoridad laboral durante el período de consultas", en: GODINO REYES, Martín (dir.), Tratado de despido colectivo, València, Tirant lo Blanch, 2016, p. 431-432.

${ }^{64}$ Sobre este motivo de impugnación, véase MOLERO MANGLANO, Carlos (dir.), et al., La llamada fase individual del despido colectivo, València, Tirant lo Blanch, 2015, p. 253.
} 
La naturaleza colectiva del proceso de impugnación colectiva del despido colectivo obliga a que en el mismo se consideren, como ya se ha anticipado, únicamente aquellas vulneraciones de derechos fundamentales y libertades públicas que revistan naturaleza colectiva, es decir, que afecten al procedimiento desde un punto de vista colectivo, y no aquellas vulneraciones de derechos fundamentales que tengan una incidencia individual, cuyo cauce procesal apropiado es el de la impugnación individual del art. 124.13 LRJS.

Por ello, en la modalidad procesal de impugnación colectiva del despido no cabe alegar vulneraciones de derechos fundamentales o posible discriminación producidas en la fase individual del procedimiento, es decir, en la extinción individual del despido efectuada por el empresario en ejecución del despido colectivo, por ejemplo, en el momento de aplicar los criterios de selección para concretar los trabajadores afectados. A dichas alegaciones les corresponde el cauce procesal de la impugnación individual del despido, la declaración de nulidad del cual no contamina la totalidad del procedimiento colectivo, que puede ser ajustado a derecho.

En cuanto a vulneraciones de derechos fundamentales y libertades públicas, cabría distinguir las siguientes:

- Vulneraciones de derechos fundamentales y libertades públicas que afecten a la decisión extintiva. En este punto se incluirían decisiones de despido colectivo que impliquen la vulneración del derecho de huelga, ${ }^{65}$ o la lesión de la garantía de indemnidad. ${ }^{66}$

- Vulneraciones de derechos fundamentales y libertades públicas que afecten a los criterios de selección y, en particular, vulneraciones en forma de discriminación prohibida. Aquí se incluirían criterios de selección de carácter discriminatorio, que afectasen a la libertad sindical (despido de trabajadores afiliados a una organización sindical), a la igualdad entre hombres y mujeres (despido de trabajadoras), a la no discriminación por razón de discapacidad (despido de trabajadores con discapacidad), etc. A su vez, dentro de este caso, habría que distinguir:

- Criterios de selección directamente discriminatorios: son los que atienden expresamente a alguna de las causas prohibidas de discriminación.

- Criterios de selección indirectamente discriminatorios: son los que atiendan a parámetros válidos y objetivos, pero tienen una incidencia sobre colectivos vulnerables y por tanto incurren en discriminación, no en su configuración, pero sí en su proyección sobre los trabajadores afectados.

- Vulneraciones de derechos fundamentales y libertades públicas que afecten a la aplicación individualizada de los criterios de selección y, en particular, vulneraciones en forma de discriminación prohibida que afecten a trabajadores individualmente considerados. Este punto se refiere a criterios de selección

${ }^{65}$ STS (Social) de 20 de abril de 2015 (Rec. 354/2014), asunto Coca cola.

${ }^{66}$ STSJ de Asturias (Social) de 23 de noviembre de 2012 (Rec. 2378/2012). 
válidos y objetivos en su configuración y en su proyección sobre el conjunto de los trabajadores, pero que, o bien han sido aplicados de manera discriminatoria sobre un trabajador en concreto (discriminación directa), o bien han sido aplicados de manera correcta pero tienen un efecto discriminatorio sobre un trabajador en concreto (discriminación indirecta), como podría ser el caso de la afectación de colectivos susceptibles de discriminación, como la trabajadora embarazada o el trabajador con discapacidad.

- Vulneración del derecho a la libertad sindical por inaplicación de las reglas de prioridad de permanencia de los representantes de los trabajadores.

Ahora bien, establecida esta clasificación, únicamente serían motivo de nulidad en la modalidad de impugnación colectiva aquellas vulneraciones que tengan incidencia colectiva. Es decir, únicamente los dos primeros supuestos, a saber: las vulneraciones que afecten a la decisión extintiva, y las que afecten a la determinación y proyección de los criterios de selección, muy en particular los criterios que resulten arbitrarios o discriminatorios. ${ }^{67}$

En cambio, las cuestiones atinentes a la aplicación individualizada de los criterios a los trabajadores afectados, quedarían reservadas a la impugnación individual del art. 124.13 LRJS, así como también las pretensiones relativas al incumplimiento de las reglas sobre prioridad de permanencia.

El propio art. 124.2 LRJS en relación con el art. 124.13 LRJS señala expresamente que en ningún caso será objeto de la impugnación colectiva el incumplimiento de las reglas sobre prioridad de permanencia de los representantes de los trabajadores. Por lo tanto, el incumplimiento de dichas reglas, tanto las establecidas legal como convencionalmente, así como las pactadas en el período de consultas, no pueden determinar la declaración de nulidad del procedimiento colectivo, pues no le afectan. ${ }^{68} \mathrm{Si}$ bien es cierto que la infracción de las reglas sobre prioridad de permanencia afecta a los derechos fundamentales (libertad sindical en el caso de los representantes legales de los trabajadores), dichas pretensiones deben canalizarse, por disposición de la ley, a través de la modalidad de impugnación individual, pues así lo señala expresamente el art. 124.2 y art. 124.13 LRJS. ${ }^{69}$

${ }^{67}$ Cabe señalar que, con anterioridad a la reforma laboral de 2012, ya se planteaban cuestiones de discriminación en los despidos colectivos. Así, puede citarse, sobre la eventual fijación discriminatoria de los criterios, la STSJ de Cataluña (Social) de 19 de febrero de 2007 (Rec. 7406/2006), en un expediente que afectaba a personas con discapacidad; o sobre discriminación indirecta por razón de género, la STSJ de Cantabria (Social) de 25 de febrero de 2009 (Rec. 112/2009), por afectar a un mayor número de mujeres en un centro en el que la mayoría de trabajadores eran hombres.

${ }^{68}$ Así lo ha señalado la SAN (Social) de 21 de noviembre de 2012 (Proc. 167/2012): "la empresa no respetó, al iniciar el período de consultas, la prioridad de permanencia de los representantes de los trabajadores [...], pero dicha infracción no constituye per se causa de nulidad del despido colectivo [...]. Descartamos, por tanto, que el incumplimiento de las reglas de prioridad, establecidas en la ley, en los convenios colectivos o en el propio período de consultas, constituya causa de nulidad del despido colectivo [...]".

${ }^{69}$ Véase PRECIADO DOMÈNECH, C. H., El nuevo proceso de despido colectivo en la Ley 3/2012, de 6 de julio, op. cit., p. 69. 
Para BLASCO PELLICER, ${ }^{70}$ la finalidad de estas complejas reglas es evitar la existencia de resoluciones judiciales divergentes. Ahora bien, la exclusión de la impugnación colectiva de las pretensiones relativas a las reglas de prioridad de permanencia de los representantes de los trabajadores plantea algún interrogante, pues en tanto que está conectada con el derecho fundamental a la libertad sindical, podría pensarse que habría de enjuiciarse a través de la pretensión del art. 124.2 d) LRJS relativa a la vulneración de derechos fundamentales y libertades públicas. Ahora bien, dicha interpretación debe ser rechazada, ya que los términos en que se expresa el art. 124.2 LRJS ("En ningún caso podrán ser objeto de este proceso las pretensiones relativas a la inaplicación de las reglas de prioridad de permanencia") son categóricos. Así lo ha confirmado el Alto Tribunal, en SSTS (Social) de 23 de septiembre de 2014 (Rec. 231/2013), y de 24 de febrero de 2015 (Rec. 165/2014). Los términos categóricos con que lo expresa, y la cercanía entre ambos preceptos son una "muestra reveladora de la voluntad del legislador", siendo el art. 124.2 in fine LRJS una excepción o limitación a la previsión del art. 124.2 d) LRJS en materia de vulneración de derechos fundamentales.

Señalan las mismas sentencias citadas que permitir la presencia en el proceso colectivo de los intereses individuales de los representantes que discuten la aplicación de la regla sobre prioridad de permanencia, haría "padecer" la arquitectura del procedimiento de despido colectivo. De hecho, esta cuestión debe conectarse con una previsión que aparece en el art. 124.13 LRJS referida a la modalidad de impugnación individual, y es que la nulidad de las extinciones realizadas sin respetar las reglas de prioridad de permanencia no afectará a las extinciones que sí las hayan respetado, tal y como señalan los arts. 124.13 a) $4^{\circ}$ y 124.13 b) $3^{\circ}$ de la LRJS. Se trata de una regla que pretende que la nulidad de los contratos que gozan de prioridad de permanencia no contamine al resto de extinciones, lo cual es justamente uno de los motivos por los que se ha relegado esta pretensión al ámbito de la impugnación individual.

Se pone de manifiesto, pues, una clara intención del legislador de no contaminar con esta cuestión el proceso colectivo, ya que, al fin y al cabo, la aplicación de las reglas de prioridad de permanencia tiene una incidencia de carácter sobre todo individual respecto del trabajador/representante afectado.

Por lo tanto, y como se ha señalado, en la impugnación colectiva sólo caben pretensiones relativas a vulneraciones de derechos fundamentales que tengan relevancia colectiva, es decir, que afecten de manera colectiva a la totalidad del procedimiento, y no a uno o varios trabajadores en particular. En relación con ello, a la hora de alegar la vulneración de derechos fundamentales y libertades públicas, conforme a la doctrina del Tribunal Constitucional, el demandante debe aportar un "indicio racional de discriminación indirecta", de suerte que permita alterar la carga de prueba y obligue al empresario a

70 BLASCO PELLICER, Á., "El proceso de impugnación del despido colectivo: el objeto del procedimiento. Las pretensiones posibles", op. cit., p. 572. 
probar que su conducta se justifica en motivos ajenos a la vulneración de derechos fundamentales. $^{71}$

La STSJ de País Vasco (Social) de 4 de septiembre de 2012 (Proc. 6/2012), que posteriormente fue parcialmente casada y anulada - pero sin afectar al pronunciamiento que nos interesa- por la STS (Social) de 28 de enero de 2014 (Rec. 16/2013), aprecia existencia de vulneración del derecho fundamental a la libertad sindical, por la desproporcionada afectación de trabajadores afiliados a una organización sindical que no era mayoritaria en la empresa.

Resulta de interés en dicha sentencia la síntesis que realiza sobre la doctrina constitucional en materia de aportación de indicios para alegar vulneración de derechos fundamentales. ${ }^{72}$ Así, cita la STC 33/2011 de 28 de marzo de 2011 (Rec. 6171/2004) y la STC 17/2003 de 30 de enero de 2003 (Rec. 1150/1999), que destacan la necesidad de "aportar un indicio razonable de que el acto empresarial lesiona su derecho fundamental, principio de prueba o prueba verosímil dirigidos a poner de manifiesto el motivo oculto que se denuncia". ${ }^{73}$ La aportación de dichos indicios produce una alteración de la carga de la prueba, de suerte que, acto seguido, corresponderá a la empresa demandada acreditar que la decisión, en este caso de afectar a los trabajadores, se debe a razones completamente ajenas a la causa discriminatoria -en el presente caso, la afiliación sindical-. ${ }^{74}$

En dicho punto cobran especial importancia los criterios de selección establecidos en el momento inicial del procedimiento, pues unos criterios de selección suficientemente precisos, claros y objetivos van a contribuir a desvirtuar los indicios de discriminación. Por el contrario, unos criterios de selección vagos y genéricos, de los que es difícil deducir lógicamente qué trabajadores van a verse afectados, contribuyen a reforzar los indicios de discriminación. De ahí la importancia que para el empresario tiene confeccionar unos criterios suficientemente claros a fin de que no tenga que hacer frente a alegaciones de

\footnotetext{
${ }^{71}$ El art. 181.2 LRJS señala: "En el acto del juicio, una vez justificada la concurrencia de indicios de que se ha producido violación del derecho fundamental o libertad pública, corresponderá al demandado la aportación de una justificación objetiva y razonable, suficientemente probada, de las medidas adoptadas y de su proporcionalidad."

72 También la STSJ de País Vasco (Social) de 9 de octubre de 2012 (Rec. 13/2012), confirmada por la STS (Social) de 18 de julio de 2014 (Rec. 11/2013), sobre vulneración del derecho de huelga y la libertad sindical, recuerda la doctrina sobre la aportación de indicios de vulneración de derechos fundamentales; así como la STSJ de Asturias (Social) de 23 de noviembre de 2012 (Rec. 2378/2012), en un proceso individual en el que se denunciaba vulneración de la garantía de indemnidad, por ser el despido una represalia frente a la acción de reclamación de salarios a instancias del trabajador, en la que se señala que "no se acredita en los autos cual ha podido ser el criterio seguido por la empresa para su designación, despejando así las dudas sobre la parcialidad denunciada".

73 STC 207/2001 de 22 de octubre de 2001 (Rec. 1515/1998); y prosigue señalando que "el indicio no consiste en la mera alegación de la vulneración constitucional, sino que debe permitir deducir la posibilidad de que ha podido producirse".

${ }^{74}$ La STS (Social) de 28 de enero de 2014 (Rec. 16/2013) destaca que la prueba indiciaria se produce en "un doble plano": el de la aportación de indicios por el trabajador, y el de la acreditación por parte de la empresa de que la decisión no tiene un móvil discriminatorio, a fin de desvirtuar dichos indicios.
} 
vulneración de derechos fundamentales, muy en particular cuando los posibles trabajadores afectados pertenezcan a colectivos susceptibles de padecer discriminación. ${ }^{75}$

En cuanto a otros posibles motivos de nulidad, además de los señalados, cabe señalar que el art. 124.11 LRJS, a diferencia de la redacción del precepto en el Real Decreto-ley $3 / 2012$, no contempla la declaración de nulidad cuando el acuerdo en el período de consultas se haya alcanzado con fraude de ley, dolo, coacción o abuso de derecho. A pesar de ello, una parte de la doctrina considera que lo más razonable es apreciar la nulidad por no haber respetado las reglas del art. 51.2 ET, es decir, realizar un período de consultas conforme a la buena fe. ${ }^{76}$ En apoyo a esta tesis, se cita el art. 148 b) LRJS, que en materia de impugnación de oficio por la autoridad laboral permite la declaración de nulidad cuando el acuerdo se haya alcanzado con fraude de ley, dolo, coacción o abuso de derecho.

Ahora bien, no constituye motivo de nulidad el incumplimiento de otros extremos regulados en otros apartados del art. 51 ET, distintos del art. 51.2 ET, como pueden ser la suscripción del convenio especial con la Seguridad Social para mayores de 55 años (art. $51.9 \mathrm{ET}$ ), o el cumplimiento de las medidas contempladas en el plan de recolocación externa (art. $51.10 \mathrm{ET}){ }^{77}$

\section{La modalidad de impugnación individual de los despidos. ${ }^{78}$}

En el ejercicio de su derecho a la tutela judicial efectiva, cada trabajador individualmente afectado tiene derecho a impugnar la extinción individual de su contrato derivada del despido colectivo. La previsión al respecto se contempla en el art. 124.13 LRJS, que remite, por lo que al procedimiento respecta, a las previsiones de los arts. 120 a 123 de la LRJS en materia de despido objetivo, aunque con ciertas especialidades. La impugnación individual de las extinciones individuales se convierte en necesaria para garantizar la tutela judicial efectiva del trabajador individualmente afectado, en tanto que en la modalidad de impugnación colectiva no tiene reconocida legitimidad activa. La competencia para conocer de las acciones individuales en materia de despido colectivo

\footnotetext{
${ }^{75}$ Sobre la carga de la prueba en despidos en los que se alegue vulneración de los derechos fundamentales, véase MONEREO PÉREZ, José Luis, La carga de la prueba en los despidos lesivos de derechos fundamentales, València, Tirant lo Blanch, 1996.

${ }^{76}$ En este sentido se pronuncia SEMPERE NAVARRO, A. V., "El proceso de impugnación del despido colectivo: la calificación del despido colectivo en la sentencia”, op. cit., p. 716-717; y BODAS MARTÍN, R., "Modificaciones de la Ley 36/2011, de 10 de octubre, reguladora de la jurisdicción social, producidas por la Ley 3/2012, de 6 de julio", op. cit., p. 534-535, a quien le provoca "fuerte perplejidad" que la nueva redacción no contemple dicha causa de nulidad.

77 Véase la STSJ de Madrid (Social) de 9 de abril de 2013 (Rec. 18/2013).

78 Sobre la impugnación individual de los despidos derivados de un procedimiento de despido colectivo, véase con más detalle BLASCO PELLICER, Á., La extinción del contrato de trabajo en la reforma laboral de 2012, op. cit., p. 113-115; PRECIADO DOMÈNECH, C. H., El nuevo proceso de despido colectivo en la Ley 3/2012, de 6 de julio, op. cit., p. 77; BODAS MARTÍN, R., "Modificaciones de la Ley 36/2011, de 10 de octubre, reguladora de la jurisdicción social, producidas por la Ley 3/2012, de 6 de julio", op. cit., p. 539 y ss.; y SÁEZ LARA, Carmen, Reestructuraciones empresariales y despidos colectivos, op. cit., p. 299 y ss.
} 
corresponde a los Juzgados de lo Social (art. 6 LRJS), y la sentencia que se dicte será recurrible en suplicación ante la Sala de lo Social del TSJ (art. 190-191.1 LRJS).

La impugnación individual se configura como el mecanismo de control judicial de la fase individual del despido colectivo, es decir, aquella en la que el empresario, tras alcanzar un acuerdo o adoptar una decisión, procede a notificar individualmente a los trabajadores su despido. Para garantizar la articulación de la impugnación individual con la eventual impugnación colectiva, el art. 124.13 b) $1^{\circ}$ de la LRJS señala que el plazo de caducidad de la impugnación individual no empieza a computar hasta que la sentencia recaída en el proceso colectivo haya adquirido firmeza.

Por otro lado, la impugnación colectiva por parte de los representantes de los trabajadores tiene efectos suspensivos sobre los procesos individuales ya iniciados, o que se inicien posteriormente, debido a la fuerza de cosa juzgada que el art. 124.13 b) $2^{\circ}$ de la LRJS confiere a la sentencia dictada en el proceso colectivo. ${ }^{79}$ Dicho precepto, además, señala que "el objeto de dichos procesos quedará limitado a aquellas cuestiones de carácter individual que no hayan sido objeto de la demanda formulada a través del proceso regulado en los apartados anteriores". Se trata de una previsión que genera cierta controversia, pues limita los motivos de impugnación admisibles, lo que demuestra la voluntad del legislador de restringir los motivos de impugnación a fin de eliminar las cuestiones de carácter colectivo que ya pudieron ser planteadas en la impugnación colectiva. ${ }^{80}$

A pesar del objetivo del legislador de garantizar una respuesta judicial rápida y homogénea respecto a los despidos, la eventual ausencia de impugnación colectiva puede desvirtuar dicho objetivo, pues no se dispondrá de una sentencia colectiva con efectos de cosa juzgada, y las impugnaciones individuales se sucederán dando lugar a respuestas tardías y plurales. ${ }^{81}$

Por su parte, la diferencia de objeto entre la modalidad colectiva y la modalidad individual plantea alguna dificultad de "deslinde" ante la común confusión entre las reglas de prioridad de permanencia en la empresa y los criterios de selección o de determinación de los trabajadores afectados. ${ }^{82}$ Confundir ambos conceptos puede ser muy problemático, ya que la regularidad de los criterios de selección es objeto de conocimiento judicial a través del proceso colectivo, mientras que las reglas de prioridad de permanencia y la aplicación individualizada de los criterios se discuten a través de la impugnación individual. A ello no contribuye nada el hecho de que muchas veces son la empresa o la representación de los trabajadores quienes en el acuerdo alcanzado confunden dichos

\footnotetext{
${ }^{79}$ Dicha fuerza de cosa juzgada es similar a la contemplada en el art. 160.5 LRJS para los procesos de conflicto colectivo.

${ }^{80}$ Así lo considera AGUSTÍ MARAGALL, J., "La coordinación entre el proceso colectivo de impugnación y los procesos individuales contra los despidos derivados del despido colectivo", op. cit., p. 796-797.

${ }^{81}$ Así lo ha apreciado BODAS MARTÍN, R., "Modificaciones de la Ley 36/2011, de 10 de octubre, reguladora de la jurisdicción social, producidas por la Ley 3/2012, de 6 de julio", op. cit., p. 509 y 547.

${ }^{82}$ Así lo destaca AGUSTÍ MARAGALL, J., "La coordinación entre el proceso colectivo de impugnación y los procesos individuales contra los despidos derivados del despido colectivo", op. cit., p. 787.
} 
conceptos, por ejemplo, estableciendo "criterios" de afectación que en realidad constituyen criterios de "preferente permanencia". ${ }^{83}$

\section{Configuración procesal de la impugnación individual.}

El art. 124.13 LRJS distingue dos cauces de impugnación individual dependiendo de que el despido colectivo haya sido objeto de impugnación colectiva o no. Así, el precepto prevé dos "submodalidades", en función de si previamente ha habido o no impugnación colectiva. ${ }^{84}$

En cuanto a los motivos de impugnación, el art. 124.13 LRJS no los señala. A falta de mención expresa en el art. 124.13 LRJS, un sector de la doctrina ha considerado que las causas de impugnación en el proceso individual no tienen restricción alguna. ${ }^{85}$ De una lectura sistemática de los arts. 120 a 124 de la LRJS pueden deducirse los motivos de impugnación posibles a través de la impugnación individual, o al menos aquellas cuestiones que pueden ser objeto de conocimiento judicial a través de la misma.

En primer lugar, cabe señalar que esta modalidad de impugnación está pensada para que el órgano judicial conozca no de los aspectos colectivos que afectan en su totalidad al procedimiento de despido colectivo o a los trabajadores afectados en su conjunto, sino que pretende ser cauce de aquellas pretensiones que versen sobre la adecuación jurídica de los despidos llevados a cabo por el empresario en la fase individual del despido colectivo, es decir, en la ejecución individual de los despidos de los concretos trabajadores afectados.

En este sentido, cabe clasificar los eventuales motivos de impugnación en función de la calificación jurídica a que darían lugar. Así, con posibilidad de que su incumplimiento diera lugar a la declaración de improcedencia del despido, esta modalidad de impugnación individual puede conocer de las pretensiones relativas al cumplimiento de los requisitos formales del despido del art. 53.1 ET, y muy en particular del requisito de entregar al

\footnotetext{
${ }^{83}$ Véase, por ejemplo, la STSJ de Madrid (Social) de 25 de junio de 2014 (Rec. 244/2014): "Tampoco son equivalentes los conceptos de preferencia en la permanencia en la empresa y de aplicación de los criterios de selección a nivel individual como consecuencia del despido colectivo. Los primeros vienen impuestos por mandato legal o convencional e, incluso, pueden establecerse en el pacto final del período de consultas. [...] Previsiones [del art. 13 RPDC] sobre derecho preferente a permanecer en la empresa que no cabe confundir con la aplicación de los criterios de afectación del personal que no goce de tal prioridad."

${ }^{84}$ Así las califica AGUSTÍ MARAGALL, J., "La coordinación entre el proceso colectivo de impugnación y los procesos individuales contra los despidos derivados del despido colectivo", op. cit., p. 789-800: impugnación individual no subordinada a impugnación colectiva, del art. 124.13 a) LRJS, e impugnación individual subordinada a impugnación colectiva, del art. 124.13 b) LRJS. Para dicho autor, llama la atención que el factor de diferenciación sea la pendencia o no de un proceso colectivo, cuando pareciera más razonable que la diferenciación dependiese del hecho de que el despido se hubiera efectuado con acuerdo o sin él. Parece razonable dicha posición, ya que el despido colectivo efectuado con acuerdo tiene un cierto carácter reforzado de cara a impugnaciones posteriores, aunque no es menos cierto que lo determinante es la existencia de un pronunciamiento judicial de carácter colectivo, pues tendrá eficacia de cosa juzgada sobre los procesos individuales ex art. 124.13 b) $2^{\circ}$ de la LRJS.

${ }^{85}$ Véase GARCÍA-PERROTE ESCARTÍN, Ignacio, "Estudio preliminar: un relevante cambio legal y de prácticas en los procedimientos de despido colectivo y de suspensión de contratos y reducción de jornada", en: GARCÍA-PERROTE ESCARTÍN, Ignacio, REYES HERREROS, Juan, (dirs.), Despido colectivo, suspensión de contrato y reducción de jornada un año después de la reforma laboral, Valladolid, Lex Nova, 2013, p. 54.
} 
trabajador una comunicación escrita de su despido "expresando la causa" ex art. 53.1 a) ET y art. 122.3 LRJS. Ello debe ponerse en conexión con la doctrina sobre la regularidad del contenido de la carta de despido, y más en particular sobre la inclusión y alcance de los criterios de selección en la misma. El Tribunal Supremo ha respaldado expresamente este modelo de impugnación. Así, la STS (Social) de 23 de septiembre de 2014 (Rec. 231/2013), asunto Agencia Pedro Laín Entralgo, señala que "las irregularidades que puedan haberse cometido en la notificación de la decisión final del despido a cada uno de los trabajadores no ha de ser examinada en el ámbito de la impugnación del despido colectivo por el cauce del artículo 124.1 de la LRJS, procediendo, en su caso, la alegación de dichas irregularidades en el procedimiento de impugnación individual de los despidos".

Por otra parte, si bien la aplicación discriminatoria o con vulneración de los derechos fundamentales de los criterios de selección, así como el incumplimiento de las reglas de prioridad de permanencia, llevan aparejados la declaración de nulidad, no sucede lo mismo con la incorrecta aplicación de los criterios de selección, para la que se reserva la declaración de improcedencia. Así lo han señalado los tribunales, por ejemplo, la STSJ de País Vasco (Social) de 10 de marzo de 2015 (Rec. 233/2015), que señala que "la ley no contempla un tratamiento específico para la violación por el empresario de los criterios de selección, lo que significa que el efecto que deriva de tan ilícita actuación no es la nulidad del despido individual, cuyas causas se regulan restrictivamente, sino su improcedencia, sin que quepa la aplicación analógica de la regla del art. 124.13 a) $4^{\circ}$ de la LRJS, al no apreciarse identidad de razón". ${ }^{86}$

También existen motivos de impugnación que pueden dar lugar a la declaración de nulidad del despido. Así, cabe citar, con independencia de que haya habido o no una impugnación colectiva, las causas de nulidad que para el despido objetivo prevé el art. 122.2 LRJS, ${ }^{87}$ y que son: despido discriminatorio o con vulneración de derechos

${ }^{86}$ AGUSTÍ MARAGALL, J., "La coordinación entre el proceso colectivo de impugnación y los procesos individuales contra los despidos derivados del despido colectivo", op. cit., p. 794, no comparte plenamente dicha conclusión, al considerar que cabría interpretar que el despido realizado sin respetar los criterios de selección se ha efectuado en fraude de ley por eludir las normas establecidas por los despidos colectivos. Aun así, tampoco resulta convincente dicha argumentación, ya que el art. 124.13 LRJS prevé la nulidad "únicamente" por la no realización del período de consultas o la no entrega de la documentación del art. 51.2 ET.

${ }^{87}$ Art. 122.2 LRJS: "La decisión extintiva será nula:

a) Cuando resulte discriminatoria o contraria a los derechos fundamentales y libertades públicas del trabajador.

b) Cuando se haya efectuado en fraude de ley eludiendo las normas establecidas por los despidos colectivos, en los casos a que se refiere el último párrafo del apartado 1 del artículo 51 del Texto Refundido de la Ley del Estatuto de los Trabajadores.

c) La de los trabajadores durante el período de suspensión del contrato de trabajo por maternidad, riesgo durante el embarazo, riesgo durante la lactancia natural, enfermedades causadas por embarazo, parto o lactancia natural, adopción o acogimiento o paternidad al que se refiere la letra d) del apartado 1 del artículo 45 del Texto Refundido de la Ley del Estatuto de los Trabajadores, o el notificado en una fecha tal que el plazo de preaviso concedido finalice dentro de dicho período.

d) La de las trabajadoras embarazadas, desde la fecha de inicio del embarazo hasta el comienzo del período de suspensión a que se refiere la letra c), y la de los trabajadores que hayan solicitado uno de los permisos a los que se refieren los apartados 4, 4 bis y 5 del artículo 37 del Texto Refundido de la Ley del Estatuto de 
fundamentales; trabajadores con contrato suspendido por motivos relacionados con la maternidad, lactancia y otros motivos familiares; trabajadoras embarazadas; o trabajadores reintegrados tras la finalización de los mencionados períodos de suspensión, salvo que hubieran transcurrido nueve/doce meses desde el nacimiento, adopción o acogimiento del hijo, salvo que se acrediten motivos ajenos a la situación personal que justifiquen el despido. ${ }^{88}$

Por lo tanto, la aplicación discriminatoria de los criterios de selección permite al trabajador afectado impugnar individualmente su afectación, a fin de que se declare la nulidad de su despido.

Por otro lado, en el supuesto de impugnación individual no subordinada a impugnación colectiva, el art. 124.13 a) $3^{\circ}$ de la LRJS contempla la nulidad del despido en el caso de que el empresario no haya celebrado el período de consultas o no haya entregado la documentación del art. 51.2 ET, pero no por el incumplimiento de otras formalidades del mismo precepto.

\section{Nulidad por no respetar las reglas de prioridad de permanencia.}

La causa de nulidad más importante en el ámbito de la impugnación individual, con independencia de que ésta esté subordinada o no a una impugnación colectiva, es el incumplimiento de las prioridades de permanencia "que pudieran estar establecidas en las leyes, los convenios colectivos o en el acuerdo alcanzado durante el periodo de consultas". ${ }^{89}$ Las pretensiones relativas a las reglas de prioridad de permanencia no se encauzan a través de la impugnación colectiva, sino a través de la individual, como se ha podido anticipar.

Por otro lado, es destacable que la ley se refiere expresamente a las reglas de prioridad de permanencia no sólo establecidas legalmente (como la de los representantes de los

los Trabajadores, o estén disfrutando de ellos, o hayan solicitado o estén disfrutando la excedencia prevista en el apartado 3 del artículo 46 de la misma Ley; y la de las trabajadoras víctimas de violencia de género por el ejercicio de los derechos de reducción o reordenación de su tiempo de trabajo, de movilidad geográfica, de cambio de centro de trabajo o de suspensión de la relación laboral, en los términos y condiciones reconocidos en el Estatuto de los Trabajadores.

e) La de los trabajadores después de haberse reintegrado al trabajo al finalizar los períodos de suspensión del contrato por maternidad, adopción o acogimiento o paternidad, siempre que no hubieran transcurrido más de nueve meses desde la fecha de nacimiento, adopción o acogimiento del hijo.

Lo establecido en las letras c), d) y e) será de aplicación, salvo que, en esos casos, se declare la procedencia de la decisión extintiva por motivos no relacionados con el embarazo o con el ejercicio del derecho a los permisos y excedencias señalados."

${ }^{88}$ Sobre ésta última cuestión, téngase presente la STSJ de País Vasco (Social) de 5 de febrero de 2019 (Rec. 74/2019), que califica como nulo el despido objetivo de una trabajadora a los 9 meses y 8 días después del parto, al considerar que la empresa ideó una estrategia para esperar a que la protección legal de la trabajadora finalizase, y no haber acreditado ningún motivo de despido ajeno a la situación familiar a la trabajadora. Por su parte, el Real Decreto-ley 6/2019, de 1 de marzo, de medidas urgentes para garantía de la igualdad de trato y de oportunidades entre mujeres y hombres en el empleo y la ocupación, ha modificado el art. 53.2 ET, ampliando la protección hasta doce meses después del nacimiento.

${ }^{89}$ Arts. 124.13 a) $4^{\circ}$ y 124.13 b) $3^{\circ}$ de la LRJS. 
trabajadores), sino también a las previstas en convenios colectivos o en el acuerdo alcanzado en el período de consultas. ${ }^{90}$

Pues bien, en los supuestos en que el motivo de impugnación sea la aplicación por parte del empresario de las reglas de prioridad de permanencia, el art. 124.13 a) $2^{\circ}$ de la LRJS establece, para la submodalidad de impugnación individual no subordinada a la impugnación colectiva, una regla de litisconsorcio pasivo necesario. Así, en estos supuestos, además de al empresario, será necesario demandar al trabajador o trabajadores beneficiados por la prioridad y respecto de los que el demandante se considere con mejor derecho. ${ }^{91}$ En este punto, la ley se refiere a las "preferencias", utilizando una nomenclatura desfasada y confusa. En consecuencia, debe entenderse "preferencia" como equivalente a prioridad de permanencia.

Esta regla alcanza, pues, a los trabajadores no afectados por la decisión de despido en virtud de una regla de prioridad de permanencia cuya aplicación el demandante reclame para sí, o bien a los trabajadores no afectados por la decisión de despido en virtud de una regla de prioridad de permanencia que el demandante considere de menor entidad que la que le corresponde a él mismo (en supuestos de prelación de varias reglas de prioridad de permanencia). ${ }^{92}$

La norma guarda silencio respecto de los supuestos en que el despido sí ha sido impugnado a través de la modalidad colectiva, en los que no se exige demandar a los trabajadores respecto de los que se discute la aplicación de la regla de prioridad de permanencia. ${ }^{93}$ La doctrina ha criticado este silencio, pues se trata de una "clamorosa disfunción" que debe ser corregida por los tribunales, aplicando por analogía la regla del litisconsorcio pasivo necesario también en los supuestos en que haya habido impugnación colectiva. ${ }^{94}$ No en balde, en ambos casos puede plantearse la discusión sobre las reglas

\footnotetext{
90 AGUSTÍ MARAGALL, J., "La coordinación entre el proceso colectivo de impugnación y los procesos individuales contra los despidos derivados del despido colectivo", op. cit., p. 794, plantea si el supuesto de nulidad incluye también las prioridades de permanencia no previstas legal o convencionalmente, ni en acuerdo alcanzado en período de consultas, sino decididas unilateralmente por el empresario en su decisión final, señalando que la lógica indica que así debe ser.

91 Art. 124.13 a) $2^{\circ}$ de la LRJS: "Cuando el objeto del debate verse sobre preferencias atribuidas a determinados trabajadores, éstos también deberán ser demandados.” A mayor abundamiento, en los supuestos de despido colectivo de personal laboral en el sector público ex D.A. 16 ${ }^{\mathrm{a}} \mathrm{ET}$, la prioridad de permanencia del personal laboral fijo "que haya adquirido tal condición a través de un procedimiento selectivo convocado al efecto y basado en los principios de igualdad, mérito y capacidad", también habrá que tener presente dicha previsión sobre el litisconsorcio pasivo necesario.

92 Véase SAN CRISTÓBAL VILLANUEVA, J. M., "El proceso de impugnación del despido colectivo: legitimación activa y pasiva", op. cit., p. 616; y BODAS MARTÍN, R., "Modificaciones de la Ley 36/2011, de 10 de octubre, reguladora de la jurisdicción social, producidas por la Ley 3/2012, de 6 de julio", op. cit., p. 544.

${ }^{93}$ La reforma operada por el Real Decreto-ley 11/2013 ha suprimido la regla de litisconsorcio pasivo necesario respecto de los representantes legales de los trabajadores en los supuestos en que se hubiera alcanzado acuerdo en el período de consultas.

${ }^{94}$ Así lo aprecia AGUSTÍ MARAGALL, J., "La coordinación entre el proceso colectivo de impugnación y los procesos individuales contra los despidos derivados del despido colectivo", op. cit., p. 791. El autor critica también la falta de rigor técnico, como se ha indicado, al referirse a las "preferencias", cuando sería más apropiado referirse a las prioridades de permanencia previstas legal o convencionalmente o establecidas en el acuerdo adoptado en el período de consultas.
} 
de prioridad de permanencia, que tienen una afectación individual, con independencia del resultado del proceso colectivo.

Otra cuestión a señalar es que el precepto no señala las consecuencias jurídicas para el codemandado en virtud de dicha regla de litisconsorcio pasivo necesario. AGUSTÍ MARAGALL, ${ }^{95}$ plantea la cuestión de si la regla de litisconsorcio pasivo necesario es también aplicable en los supuestos en que se discuta la aplicación de los criterios de selección, debiendo demandar también al trabajador o trabajadores no afectados respecto de los que el impugnante se considere con mejor derecho, cuestión sobre la que es difícil estar de acuerdo, por la enorme complejidad que entrañaría, y porque los criterios de selección no tienen la misma configuración que las reglas de "prioridad", que por definición implican una ordenación de unos trabajadores frente a otros. De hecho, la STSJ de Cataluña (Social) de 17 de noviembre de 2015 (Rec. 4048/2015) ha rechazado dicha posibilidad. ${ }^{96}$

La llamada a juicio de los trabajadores no afectados respecto de los que el demandante se considere con mejor derecho plantea no pocas complejidades. En primer lugar, exigiría al trabajador afectado hacer un ejercicio de selección de afectados, aplicando los criterios de selección, lo cual corresponde únicamente al empresario. Por su parte, sólo el empresario dispone de información y datos suficientes sobre la totalidad de la plantilla para realizar la aplicación de los criterios de selección, resultando una tarea de gran complejidad para el trabajador afectado. En este sentido, el trabajador afectado sí que puede discutir la incorrecta aplicación de los criterios de selección por lo que a él respecta, pero no dilucidar qué otros trabajadores debieran haber sido afectados.

Además, hay otro elemento a tener en cuenta, y es la diferencia conceptual entre los "criterios", en tanto que parámetros que el empresario considera para elegir a los afectados, y las "prioridades de permanencia", que suponen reglas que expresan preferencia para permanecer en la empresa con respecto a otro trabajador. Por ello, sólo en el caso de las antes llamadas "preferencias" o prioridades de permanencia, es posible discutir la afectación en confrontación con otro trabajador respecto del que el afectado se considere con mejor derecho, pero no en el caso de los criterios de selección. Así, la prioridad de permanencia expresa que un trabajador tiene prioridad para permanecer en la empresa, prioridad que se proyecta con respecto a otro u otros trabajadores.

Volviendo a la regla de litisconsorcio pasivo necesario en casos en que se discuta la aplicación de reglas de prioridad de permanencia, el propio precepto establece una cautela

\footnotetext{
${ }^{95}$ AGUSTÍ MARAGALL, J., "La coordinación entre el proceso colectivo de impugnación y los procesos individuales contra los despidos derivados del despido colectivo", op. cit., p. 791.

${ }^{96}$ También la STSJ de Madrid (Social) de 25 de junio de 2014 (Rec. 244/2014): "Tampoco son equivalentes los conceptos de preferencia en la permanencia en la empresa y de aplicación de los criterios de selección a nivel individual como consecuencia del despido colectivo. [...] Por ello, no es menester en principio traer al pleito a quienes no se vieron concernidos por el criterio de designación directa y por ende forzosa de la mercantil codemandada, lo que además habría complicado sobremanera el desarrollo del proceso judicial, volviéndolo ingobernable." Es habitual encontrar terminología confusa al respecto. Véase, por ejemplo, la STSJ de Galicia (Social) de 2 de mayo de 2013 (Rec. 10/2013), que se refiere a "criterios de prioridad de permanencia del personal".
} 
expresa, señalando que la eventual declaración de nulidad "no afectará a las extinciones que dentro del mismo despido colectivo hayan respetado las prioridades de permanencia", lo cual evita el "efecto contaminante" de la nulidad del despido individual sobre el resto de extinciones. ${ }^{97}$ Dicha cautela viene a confirmar la intención del legislador de dejar las cuestiones relativas a las reglas sobre prioridad de permanencia en el plano estrictamente individual, sin afectar ni siquiera a otras extinciones individuales.

Finalmente, cabe señalar que corresponde al empresario probar el cumplimiento de las reglas sobre prioridad de permanencia, justificando la eventual afectación por el despido de trabajadores titulares de alguna prioridad. Así lo señala expresamente el art. 13.3 RPDC, al afirmar que "la empresa deberá justificar en la decisión final de despido colectivo a que se refiere el artículo 12, la afectación de los trabajadores con prioridad de permanencia en la empresa". No en balde, las reglas de prioridad de permanencia están íntimamente ligadas con el ejercicio de derechos fundamentales, y de ahí se extrae que el legislador haya querido sancionar con la nulidad las extinciones realizadas en contravención de las mismas. Así, la prioridad de permanencia de los representantes de los trabajadores está íntimamente ligada con el derecho fundamental a la libertad sindical. El resto de prioridades de permanencia que pudieran establecerse vía convencional, normalmente atenderán a la protección de colectivos socialmente vulnerables sobre los que podrían producirse afectaciones discriminatorias, a fin de que queden a salvo de las extinciones.

En este sentido, la STSJ de Madrid (Social) de 12 de marzo de 2012 (Rec. 823/2012) señala que "la preferencia que otorga la protección de los derechos fundamentales, aplicada al derecho de prioridad de permanencia, obliga a la empresa a acreditar en el expediente de regulación la concurrencia de razones organizativas o productivas de entidad que justifiquen la exclusión de aquel derecho [...], pues, en otro caso, ha de entenderse que prima la garantía legalmente establecida", conectándolo con la doctrina constitucional de alteración de la carga de la prueba en materia de indicios de discriminación, aplicable frente a vulneraciones de derechos fundamentales. ${ }^{98}$

\section{Conclusiones.}

El modelo de impugnación del despido colectivo contemplado en el art. 124 LRJS adolece de una enorme complejidad en la que se prevén distintas formas de impugnación no siempre bien articuladas entre sí. A parte de la impugnación de oficio por la autoridad laboral - una de las pocas formas de control sobre el despido colectivo que le restan-y la

\footnotetext{
97 Arts. 124.13 a) $4^{\circ}$ y 124.13 b) $3^{\circ}$ de la LRJS. Sobre la evitación del "efecto contaminante", véase BLASCO PELLICER, Á., La extinción del contrato de trabajo en la reforma laboral de 2012, op. cit., p. 115.

98 Así, continúa señalando: “Aquel carácter preferente determina la inversión del onus probandi (carga de la prueba) en la acreditación de las causas que justifican el carácter no discriminatorio o antisindical del despido si por el trabajador se aducen hechos de entidad suficiente para abrir razonablemente la hipótesis de la vulneración del derecho fundamental”, en los términos de la STC 17/2003 de 30 de enero de 2003 (Rec. 1150/1999).
} 
acción declarativa a instancias del empresario en supuestos de no impugnación colectiva, el despido colectivo puede impugnarse por dos vías: la vía colectiva a instancias de los representantes de los trabajadores, y la vía individual a instancias del trabajador afectado.

Sin desmerecer las buenas intenciones del legislador al configurar dicho sistema, la realidad es que en los años posteriores a la reforma laboral de 2012 la litigiosidad en materia de despido colectivo ha sido muy elevada, así como las dudas planteadas en torno a los efectos de las sentencias dictadas de conformidad con las distintas vías de impugnación.

La vía colectiva pretende dar cauce a las pretensiones relativas a la irregularidad del procedimiento de despido colectivo en su conjunto, y prevé como causas de nulidad la no realización del período de consultas, la no entrega de la documentación del art. 51.2 ET, y la vulneración de los derechos fundamentales del trabajador. Sobre la aportación de documentación y, en especial, los criterios de selección, habrá que estar a la interpretación finalista dada por los tribunales, de suerte que sólo dan lugar a la nulidad aquellos incumplimientos documentales que resulten transcendentes $\mathrm{y}$ hayan afectado negativamente el desarrollo del período de consultas. A ello debe sumarse la cuestión del nivel de precisión de los criterios de selección, ya que habrá que estar al caso concreto, pues la ley exige la aportación de los criterios de selección, pero no exige un nivel de concreción al respecto, si bien hay que entender que los criterios claramente genéricos y que impidan la negociación deben llevar aparejada la declaración de nulidad.

Para valorar los distintos casos y determinar la suficiencia de los criterios, los tribunales atienden a circunstancias como el volumen de la plantilla, el conocimiento por parte de los representantes de qué trabajadores iban a verse afectados, la progresiva concreción de los criterios a lo largo del período de consultas, la final adopción de un acuerdo, y la falta de alegación en contra por parte de los representantes (doctrina de los propios actos). Lo mismo cabe afirmar de otros extremos, como el número de afectados o su clasificación profesional, así como de una eventual aportación tardía de la documentación. Precisamente las cuestiones documentales se han convertido en una de las fuentes de mayor litigiosidad en el despido colectivo.

Por su parte, los tribunales han establecido mayoritariamente que únicamente la ausencia total de aportación de los criterios puede llevar aparejada consigo una consecuencia tan drástica como la declaración de nulidad de todo el procedimiento de despido colectivo en su conjunto, y ello con independencia de la mayor o menor precisión de los criterios. Eso sí, habrá que atender a las circunstancias de la empresa y al concreto desarrollo del procedimiento de despido colectivo.

En cuanto a la nulidad por vulneración de los derechos fundamentales, por vía colectiva sólo cabe alegar aquellas vulneraciones que afecten al procedimiento en su conjunto. Así, en los criterios de selección, cabe alegar la existencia de criterios de selección que sean directamente discriminatorios, o bien indirectamente discriminatorios por afectar claramente a un colectivo concreto, si bien la presencia de un criterio discriminatorio puede llevar a la anulación del criterio en cuestión, sin afectar a los demás. 
Por otro lado, las cuestiones que afectan al despido individual del concreto trabajador afectado se enjuician a través de la impugnación individual del art. 124.13 LRJS, que a su vez contempla dos submodalidades en función de si el despido ha sido o no impugnado colectivamente.

En dicha vía individual cabe alegar cuestiones como la relativa al contenido de la carta individual de despido, o la incorrecta aplicación de los criterios de selección, casos en que el despido será calificado de improcedente. En cambio, otras pretensiones dan lugar a la calificación de nulidad, como el despido realizado con vulneración de los derechos fundamentales o por razones discriminatorias - por aplicación discriminatoria de los criterios de selección-, o el incumplimiento de las reglas en materia de prioridad de permanencia.

En éste último caso, y para la submodalidad de impugnación individual no subordinada a la impugnación colectiva, se prevé una regla de litisconsorcio pasivo necesario según la cual el trabajador debe demandar al trabajador respecto del que se considera con mejor derecho, lo cual plantea numerosas dificultades, ya que al trabajador no le corresponde sustituir al empresario en su tarea de seleccionar a los afectados, por lo que sería conveniente plantear un debate sobre la subsistencia de dicha regla. De hecho, para la submodalidad subordinada a la impugnación colectiva, dicha regla ya no se prevé, lo cual ha generado un debate entre la doctrina.

En definitiva, sería interesante plantear un debate sobre la modificación, o al menos adaptación del marco legal del sistema de impugnación del despido colectivo, a fin de aportar cierta claridad y de solucionar los problemas que ha planteado en los últimos años.

\section{Bibliografía.}

AGUSTÍ MARAGALL, Joan, "Más cuestiones sobre el nuevo proceso judicial de impugnación colectiva del despido colectivo (art. 124 LRJS)", Jurisdicción Social, núm. 118,2012

AGUSTÍ MARAGALL, Joan, "La coordinación entre el proceso colectivo de impugnación y los procesos individuales contra los despidos derivados del despido colectivo”, en: GODINO REYES, Martín (dir.), Tratado de despido colectivo, València, Tirant lo Blanch, 2016

ARASTEY SAHÚN, María Lourdes, "El período de consultas: la solicitud y entrega de información y documentación no prevista legalmente", en: GODINO REYES, Martín (dir.), Tratado de despido colectivo, València, Tirant lo Blanch, 2016 
BALLESTER LAGUNA, Fernando, La impugnación del despido colectivo (en el marco del artículo 124 de la Ley 36/2011, de 10 de octubre, reguladora de la jurisdicción social), València, Tirant lo Blanch, 2013

BLASCO PELLICER, Ángel Antonio, La extinción del contrato de trabajo en la reforma laboral de 2012, València, Tirant lo Blanch, 2013

BLASCO PELLICER, Ángel Antonio, "El proceso de impugnación del despido colectivo: el objeto del procedimiento. Las pretensiones posibles", en: GODINO REYES, Martín (dir.), Tratado de despido colectivo, València, Tirant lo Blanch, 2016

BODAS MARTÍN, Ricardo, "Modificaciones de la Ley 36/2011, de 10 de octubre, reguladora de la jurisdicción social, producidas por la Ley 3/2012, de 6 de julio", en: GARCÍA-PERROTE ESCARTÍN, Ignacio, MERCADER UGUINA, Jesús Rafael, (dirs.), Reforma laboral 2012. Análisis práctico del RDL 3/2012, de medidas urgentes para la reforma del mercado laboral, Valladolid, Lex Nova, 2012

CERVERA SOTO, Teresa, CID BABARRO, Carlos, El despido colectivo: claves prácticas y análisis jurisprudencial, Valladolid, Lex Nova, 2016

DESDENTADO BONETE, Aurelio, "Comentario al artículo 124 LRJS", en: MERCADER UGUINA, Jesús Rafael (dir.), Ley reguladora de la jurisdicción social comentada y con jurisprudencia, Madrid, La Ley, 2015

FOLGUERA CRESPO, José Ángel, "El impacto de la reforma laboral en el proceso", en: GARCÍA-PERROTE ESCARTÍN, Ignacio, MERCADER UGUINA, Jesús Rafael, (dirs.), La aplicación práctica de la reforma laboral: un estudio de Ley 3/2012 y de los Reales Decretos-leyes 4/2013 y 5/2013, Valladolid, Lex Nova, 2013

GARCÍA-PERROTE ESCARTÍN, Ignacio, "Estudio preliminar: un relevante cambio legal y de prácticas en los procedimientos de despido colectivo y de suspensión de contratos y reducción de jornada", en: GARCÍA-PERROTE ESCARTÍN, Ignacio, REYES HERREROS, Juan, (dirs.), Despido colectivo, suspensión de contrato y reducción de jornada un año después de la reforma laboral, Valladolid, Lex Nova, 2013

GIL PLANA, Juan, "El despido colectivo: aspectos sustantivos", en VV.AA., MONTOYA MELGAR, Antonio, GARCÍA MURCIA, Joaquín (dirs.), Comentario a la reforma laboral de 2012, Madrid, Civitas, 2012

GIL PLANA, Juan, "Reforma procesal del despido colectivo y otras novedades procesales", en: THIBAULT ARANDA, Javier (dir.), JURADO SEGOVIA, Ángel (coord.), La reforma laboral de 2012: nuevas perspectivas para el derecho del trabajo, Madrid, La Ley, 2012. 
GOERLICH PESET, José María, "La extinción del contrato de trabajo en la reforma de 2012: la culminación de una larga evolución", en: GARCÍA-PERROTE ESCARTÍN, Ignacio, MERCADER UGUINA, Jesús Rafael, (dirs.), La regulación del Mercado Laboral. Un análisis de la Ley 3/2012 y de los aspectos laborales del Real Decreto-ley 20/2012, Valladolid, Lex Nova, 2012

GOERLICH PESET, José María, "Desarrollo y contenido de las consultas", en: AA.VV., Los períodos de consultas, Colección Informes y Estudios, Serie Relaciones Laborales núm. 104, Madrid, Ministerio de Empleo y Seguridad Social, 2014

GOÑI SEIN, José Luis, "El nuevo modelo normativo de despido colectivo implantado por la Ley de reforma laboral de 2012”, Documentación Laboral, núm. 95-96, 2012

LOUSADA AROCHENA, José Francisco, RON LATAS, Ricardo Pedro, "La modalidad procesal de despidos colectivos", Diario La Ley, núm. 7863, 2012

MARTÍNEZ MORENO, Carolina, "La nulidad en el despido colectivo: causas y límites", en: AA.VV., Encuentro de magistrados de la Sala Cuarta del Tribunal Supremo con presidentes de las Salas de lo Social de los Tribunales Superiores de Justicia y de la Audiencia Nacional: La reforma laboral. Problemas sustantivos y procesales en su aplicación, Cuadernos Digitales de Formación, núm. 24, Madrid, Consejo General del Poder Judicial, 2013

MERCADER UGUINA, Jesús Rafael, "El período de consultas: la intervención de la autoridad laboral durante el período de consultas”, en: GODINO REYES, Martín (dir.), Tratado de despido colectivo, València, Tirant lo Blanch, 2016

MOLERO MANGLANO, Carlos (dir.), et al., La llamada fase individual del despido colectivo, València, Tirant lo Blanch, 2015

MOLERO MARAÑÓN, María Luisa, "La nueva modalidad procesal de impugnación judicial del despido colectivo", Relaciones Laborales, núm. 23-24, 2012

MONEREO PÉREZ, José Luis, La carga de la prueba en los despidos lesivos de derechos fundamentales, València, Tirant lo Blanch, 1996

MONEREO PÉREZ, José Luis, "El nuevo procedimiento de regulación de empleo (en contraste con el antes denominado "expediente" de crisis)", Revista General de Derecho del Trabajo y de la Seguridad Social, núm. 34, 2013

MONEREO PÉREZ, José Luis, "Intervención administrativa en los despidos colectivo", Temas Laborales: Revista Andaluza de Trabajo y Bienestar Social, núm. 125, 2014 
PUEBLA PINILLA, Ana de la, "Exigencias documentales en el despido colectivo: del RDL 3/2012 a la Ley 3/2012. STSJ Madrid 30 mayo 2012”, Aranzadi Social, núm. 7, 2012

PUEBLA PINILLA, Ana de la, "Las paradojas del despido colectivo tras la supresión de la autorización administrativa", Teoría y Derecho, núm. 13, 2013

PRECIADO DOMÈNECH, Carlos Hugo, El nuevo proceso de despido colectivo en la Ley 3/2012, de 6 de julio, Albacete, Bomarzo, 2013

ROQUETA BUJ, Remedios, La selección de los trabajadores afectados por los despidos colectivos, València, Tirant lo Blanch, 2015

SÁEZ LARA, Carmen, Reestructuraciones empresariales y despidos colectivos, València, Tirant lo Blanch, 2015

SAN CRISTÓBAL VILLANUEVA, Juan Manuel, "El proceso de impugnación del despido colectivo: legitimación activa y pasiva”, en: GODINO REYES, Martín (dir.), Tratado de despido colectivo, València, Tirant lo Blanch, 2016

SEMPERE NAVARRO, Antonio Vicente, "El proceso de impugnación del despido colectivo: la calificación del despido colectivo en la sentencia", en: GODINO REYES, Martín (dir.), Tratado de despido colectivo, València, Tirant lo Blanch, 2016

TASCÓN LÓPEZ, Rodrigo, "La impugnación del despido colectivo tras la reforma laboral: el Derecho del Trabajo en su laberinto", Revista de Trabajo y Seguridad Social, núm. 353-354, 2012

TASCÓN LÓPEZ, Rodrigo, "Problemas prácticos en la impugnación del despido colectivo”, Aranzadi Social: Revista Doctrinal, núm. 10, 2013 